\title{
Numerical analysis of two pile caps with sockets embedded, subject the eccentric compression load
}

\section{Análise numérica de blocos sobre duas estacas com cálice embutido, submetido à ação de força de compressão excêntrica}
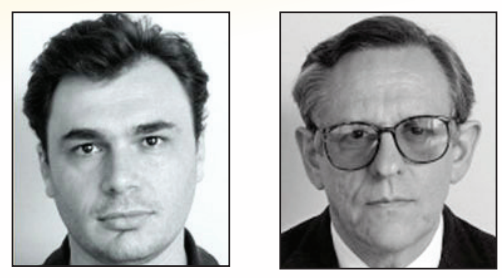

R. G. DELALIBERA a delalibera@pq.cnpq.br

J. S. GIONGO b jsgiongo@sc.usp.br

\begin{abstract}
The structural behavior of pile caps with sockets embedded is influenced by interface of column-socket, which can be smooth or rough. With intent to analyze the behavior of two pile caps with embedded socket, considering the friction between the column and the socket, with eccentric normal load, the numerical simulations were carried out, using a program based on the Finite Element Methods (FEM). In the numerical analysis the non-linear behavior of materials was considered, also the friction between the column and the socket. It was considered perfect bond between the reinforcement and the concrete around. It was observed that the embedded length is preponderant factor in the structural behavior of the analyzed element.
\end{abstract}

Keywords: pile caps, foudations, precast concrete.

\section{Resumo}

O comportamento estrutural dos blocos sobre estacas com cálice embutido é influenciado pelo tipo de interface pilar-cálice, a qual pode ser lisa ou rugosa. Com o objetivo de analisar o comportamento de blocos sobre duas estacas com cálice embutido, considerando a rugosidade da interface pilar-cálice, submetido à ação de força normal excêntrica, realizaram-se simulações numéricas, desenvolvidas em programa de computador baseado no método dos elementos finitos - MEF. Na análise numérica as não-linearidades físicas dos materiais concreto e aço foram consideradas, como também o atrito nas interfaces entre as paredes do pilar e do cálice. Considerou-se aderência perfeita entre as barras de aço das armaduras com o concreto do entorno. Observou-se que o comprimento de embutimento do pilar no interior do bloco é fator preponderante no comportamento estrutural do elemento em análise.

Palavras-chave: blocos sobre estacas; fundações; concreto pré-moldado.

Departamento de Engenharia Civil, Universidade Federal de Goiás - Campus Catalão, dellacivil@pq.cnpq.br, Av. Lamartine Pinto de Avelar, 1120, CEP: 75704-020, Catalão - GO, Brasil.

b Departamento de Engenharia de Estruturas, Escola de Engenharia de São Carlos, Universidade de São Paulo, jsgiongo@sc.usp.br,

Av. Trabalhador Sãocarlense, 400, CEP: 13566-590, São Carlos - SP, Brasil. 


\section{Introduction}

The choice of the kind of foundation is made after analysis which considers the technical and economic conditions of the building, the vicinity of the neighboring buildings, the nature and characteristic of the soil, the magnitude of the actions and of the kinds of foundations available in the market.

The foundations in piles are adopted when the soil in its superficial layers is not able to stand actions from the superstructure, being necessary, therefore, to consider strength in deep layers. When using solution in deep foundation by piles, it is necessary the construction of another structural element, the pile caps.

According to NBR 6118:2007[1], pile caps are important structural elements which function is to transfer the actions of the superstructure to a group of piles. These structural elements, in spite of being essential to the safety of the superstructure, usually does not allow the visual inspection while working, thus, it is important the knowledge of its real behavior in the Limit States of Service and Last . Figure [1] illustrates this structural element.

When the superstructure is precast it is necessary that the column is built-in on the pile. The length of the built-in of the column within the pile, so that it is considered clamped, it is function of the internal forces (bending, normal force and shear force) and the kind of superficial shape of the walls (rough or smooth) of the precast and column concrete. The lengths of embed are definite by NBR 9062:2006[2]. There are some variations in the types of pile with precast (external precast, partially embed precast and totally embed precast). Figure [2] shows the variations of the blocks on piles for precast columns. The technical mean uses more intensely the blocks with external precast and partially embed.

The European code (EUROCODE 2) EN 1992-1-1 [3] presents recommendations regarding the precast project for linking columnfoundation, considering the monolithic behavior of the set when using "shear key". For the smooth conformation of the precast and the column walls, it indicates that the friction coefficient between the column faces and the precast faces is higher than 0.3 and the embed length higher or equal to 1.2 times the biggest column dimension.

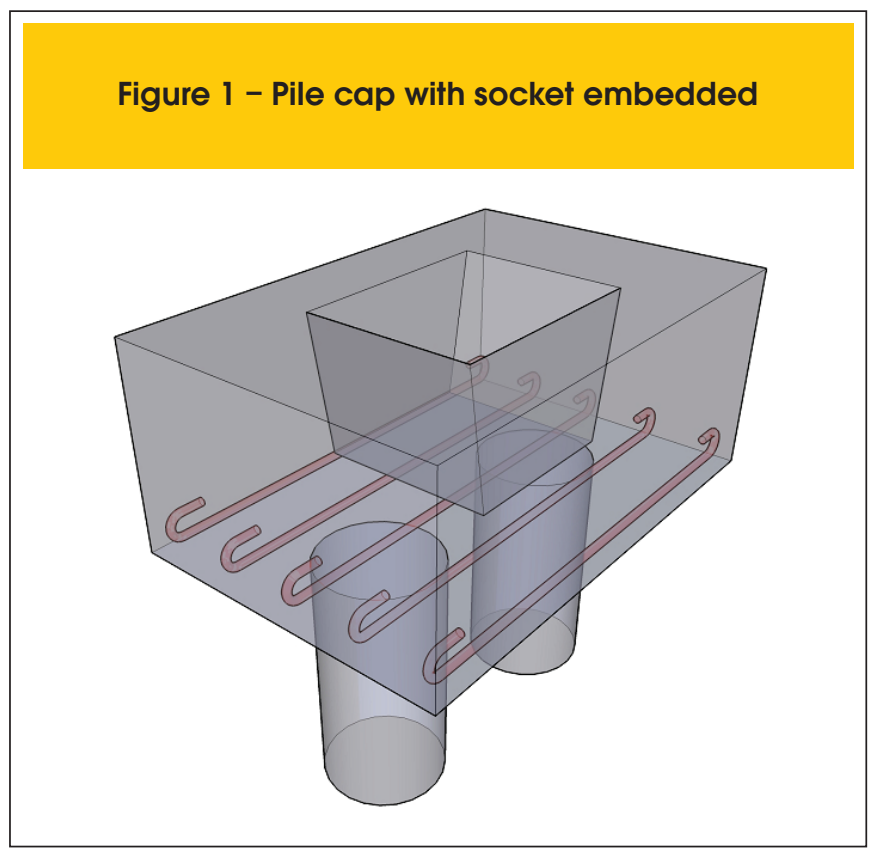

As there is no consensus between the scientific means in relation to the section of the pile cap where it forms the stanchion (or connecting rod), a numeric analysis was performed, aiming at observing the structural behavior of the pile caps. Thereunto, eighteen two piles caps were analyzed, nine with rough interface and nine with smooth interface.

The embed length of the column $\left(\ell_{\text {emb }}\right)$ and the thickness of the bottom slab of the pile cap $\left(h_{s}\right)$ were assorted. Thus, the embed lengths of the precast columns were equal to $80 \mathrm{~cm}$, $60 \mathrm{~cm}$ and $50 \mathrm{~cm}$. The thicknesses of the bottom slab were equal to $30 \mathrm{~cm}, 20 \mathrm{~cm}$ and $10 \mathrm{~cm}$. Bottom slab, it is not the best term to express the dimension $h_{s}$ because there is not such a slab in the bottom of the block. Although, it is considered that this term is the one which presents better understanding to the readers.

\section{Figure 2 - Pile caps with external socket, partly embedded e fully embedded}

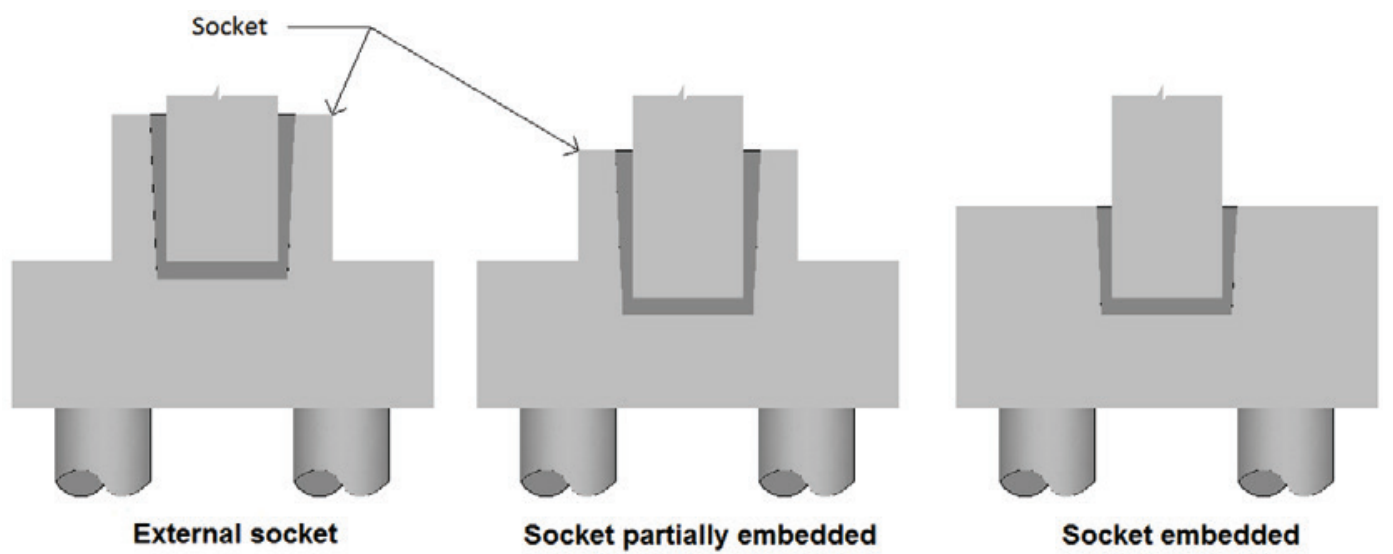


The purpose of this work is to analyze the structural behavior of two piles caps with embed precast, with smooth and rough interfaces of the walls of the column and the precast, subject to the action of normal eccentric compression force and, verify by variance analysis, which variable presents the biggest relevance in their behavior.

The method used was the one related to works with emphasis in numeric analysis. Definite the models which were studied, it was developed a statistical analysis, using values obtained by numeric simulations. The pile caps were numerically analyzed by a computer program based on the methods of the finite elements - MEF. The physical and geometrical nonlinearities were considered. The cracking of the concrete and the reinforcement of the pile caps were also taken into account. For the numerical analysis of the pile caps via method of the finite elements, it was used the program ANSYS $^{\circledR}[23]$ (ANalyser SYStem).

\section{Geometric properties of the numerically analyzed models}

The models were dimensioned with the criteria of Blévot \& Frémy [4]. The rates of reinforcement were fixed, because they were not analysis objects. The distance between the axles of the piles was also fixed, varying the length of the embed of the column $\left(\ell_{\text {emb }}\right)$ and the thickness of the pile cap bottom slab $\left(h_{s}\right)$. The dimensioning of the main reinforcement of the pile cap (tie) and the verifications of the crushing of the concrete of the compressed diagonal with the inferior nodal zone (pile/pile cap) and with the superior nodal zone (column/pile cap) were performed according to the recommendations of the model proposed by Blévot \& Frémy [4]. It was used as limits to verify the stress with the superior and inferior nodal zones the values observed by the French researchers, in other words, $1,40 \cdot f_{c k}$ near the column and $f_{c k}$ near the pile.

We opted for using straight anchoring, because it was verified through the recommendations of the NBR 6118:2007[1] that the hook was not necessary (anchoring criteria in extreme supports). By admitting this hypothesis the researcher did not consider (project decision) the recommendation of NBR 6118:2007[1] which demands the use of hooks in pile caps. We remember the results obtained by Delalibera [5], Miguel [6] e Adebar et al. [7], for rigid pile caps, where the stress on the tip of the rod was negligible, corroborating this decision.

For the dimensioning of the pile caps, we used a pattern pile cap, in other words, all pile caps had the same dimensions in plant of the pattern pile cap, varying only the embed length of the column $\left(\ell_{\text {emb }}\right)$ and the thickness of the pile cap bottom slab $\left(h_{s}\right)$. It is understood,

\section{Figure 3 - Geometric properties of standard pile cap}
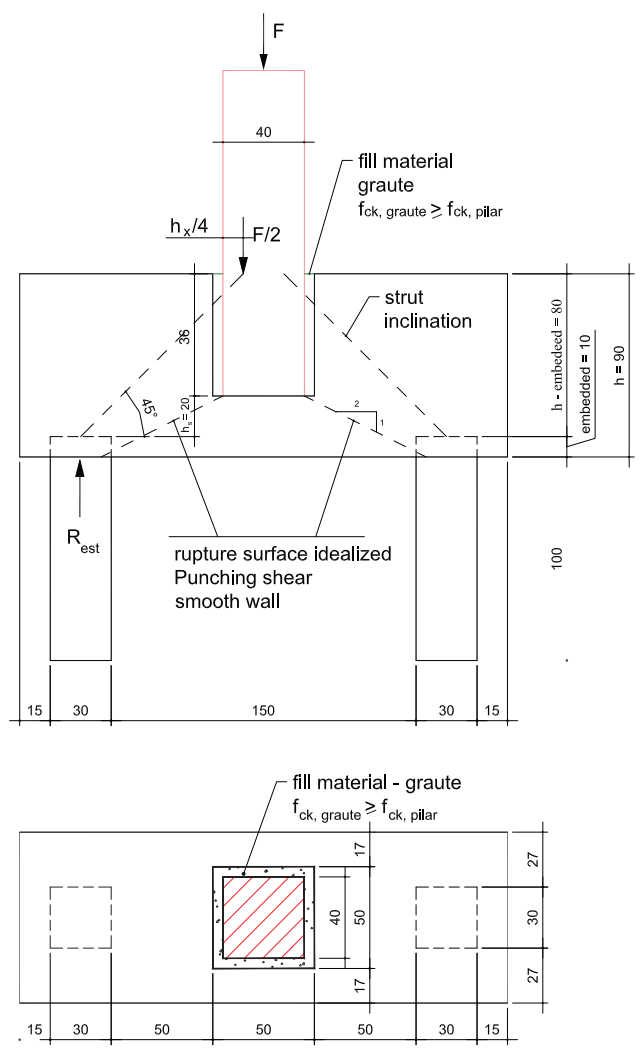

A Dimension

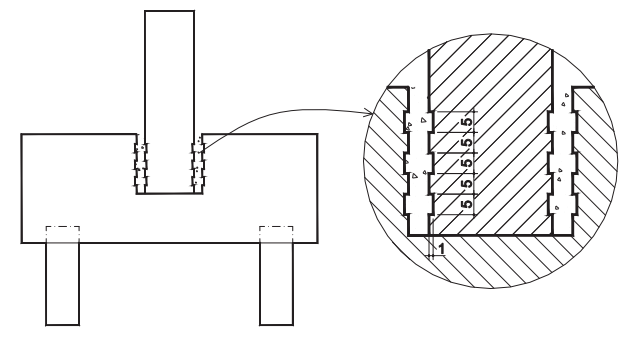

B Shear key 
so, that the total heights of the models and the inclination angles of the compression rod also suffered variations. For the pattern pile cap we adopted piles of squared transversal section equal to 30 $\mathrm{cm}$ side, column also with squared transversal section, however with $40 \mathrm{~cm}$ side. The embed length of the column in the pattern pile cap was equal to $60 \mathrm{~cm}$. This value represents the minimal embed length for smooth walls (precast and column) specified in NBR 9062:2006 [2], when the relation $\left[M_{d} /\left(N_{d} \cdot h\right)\right] \leq 0,15$. Figure [3] presents the geometric properties of the pattern pile cap.

The distance between the axles of the piles was determined in function of the inferior limit angle established by the French researchers, in other words, $45^{\circ}$. Therefore, the total height of the pattern block was equal to $90 \mathrm{~cm}$, and the dimensions in plants were equal to $240 \mathrm{~cm}$ for $84 \mathrm{~cm}$. The distance between the axles of the piles of all pile caps was equal to a hundred eight centimeters. The embed length of the piles in the inferior face of the pile caps followed the suggestion of the Montoya et al. [8], namely, it was inlaid ten centimeters of the pile shaft inside the pile cap.

In relation to the columns and the piles the compression strength concrete was equal to $50 \mathrm{MPa}$ seeking to avoid, thus, ruining these elements. The reinforcement of the piles were composed by eight steel bars with a $20 \mathrm{~mm}$ diameter with strength equal to $500 \mathrm{MPa}$, totalizing an steel area equal to $32.7 \mathrm{~cm}^{2}$. The external length of the column was equal to $100 \mathrm{~cm}$.

For the filling material, we adopted compression strength concrete equal to $50 \mathrm{MPa}$ (value equal compression strengths concrete of the column).

Figure [4] shows the factors which present variations in the numerical analysis.

Table [1] presents the properties of the analyzed pile caps in relation to the conformation of the smooth walls and to the shear key (rough), requested by the compression force supposedly centered in the column and by a horizontal force applied on the top of the column.

The nomenclature used in Table [1] is described: L, pile with smooth conformation of the walls of the precast and the column; $R$, rough conforma-tion of the precast and the column; $\ell_{e} 80$, embed of the column equal to eighty centimeters (more numbers are analogue); $h_{s} 30$, thickness of the bottom slab equal to thirty centimeters (more numbers are analogue); NM means that eccentric compression force was applied.

In the same table, $A_{\mathrm{st}}$ represents the area of the transversal section of the reinforcement class CA-50, $B_{1 x}$ the length of the pile cap, $B_{1 y}$ the breadth of the pile cap, $\ell_{\text {emb }}$ the embed length of the precast column and $h_{s}$, the thickness of the pile cap bottom slab.

Using the indications of Blévot \& Frémy [4], it was performed a forecast of the resistant capacities of the pile caps.

\section{Numerical analysis}

The goal of the numerical analysis was to provide results for the application of a statistical analysis named ANOVA (variance analysis), thus, two piles caps with embed precast, with conformation of the smooth and rough walls were analyzed. The numerical analysis did not aim at calibrating bends of experimental results, but presenting behavior trends of the analyzed models.

The geometry of all models were created in the computer program AutoCad $^{\circledR}$ and exported to the computer program ANSYS ${ }^{\circledR}$ [23], through the extension SAT.
Figure [5] presents the finite elements net used to discretization of the elements of the volume (concrete) and the bar elements (steel bars of the reinforcement).

The normal force was considered through a pressure of $20 \mathrm{MPa}$ applied on the top of the column. The moment was considered through a horizontal force, also applied on the column top, which value was equal to $100 \mathrm{kN}$, generating a moment in the column base of $100 \mathrm{kNm}$. See Figure [04].

As the models were symmetric, it was used the resource of symmetry. Therefore, it was analyzed only half of the structural element. The translations were restricted (in the three directions, $x, y$ and $z$ ) of the element nodes placed on the tips of the piles. Figure [6] presents the conditions of shape used in the models.

The length of a meter of the piles and the column, was chosen in function of the principle of Saint - Venant, thus, the influences were eliminated from the disturbances of stress in the areas of application of the forces and in the areas of translation restrictions.

\subsection{Finite element used}

For the modeling of the concrete material, we used the finite element Solid 65. This element has eight nodes with three degrees of freedom per node - translations in the directions $x, y$ and $z$. The element presents plastic deformations, cracking and crushing in three orthogonal directions. In the element Solid 65 , the cracking occurs when the main stress of the traction in any direction reaches the rupture superficies. After the cracking, the elasticity module of the concrete has value equal to zero in the considered direction. The

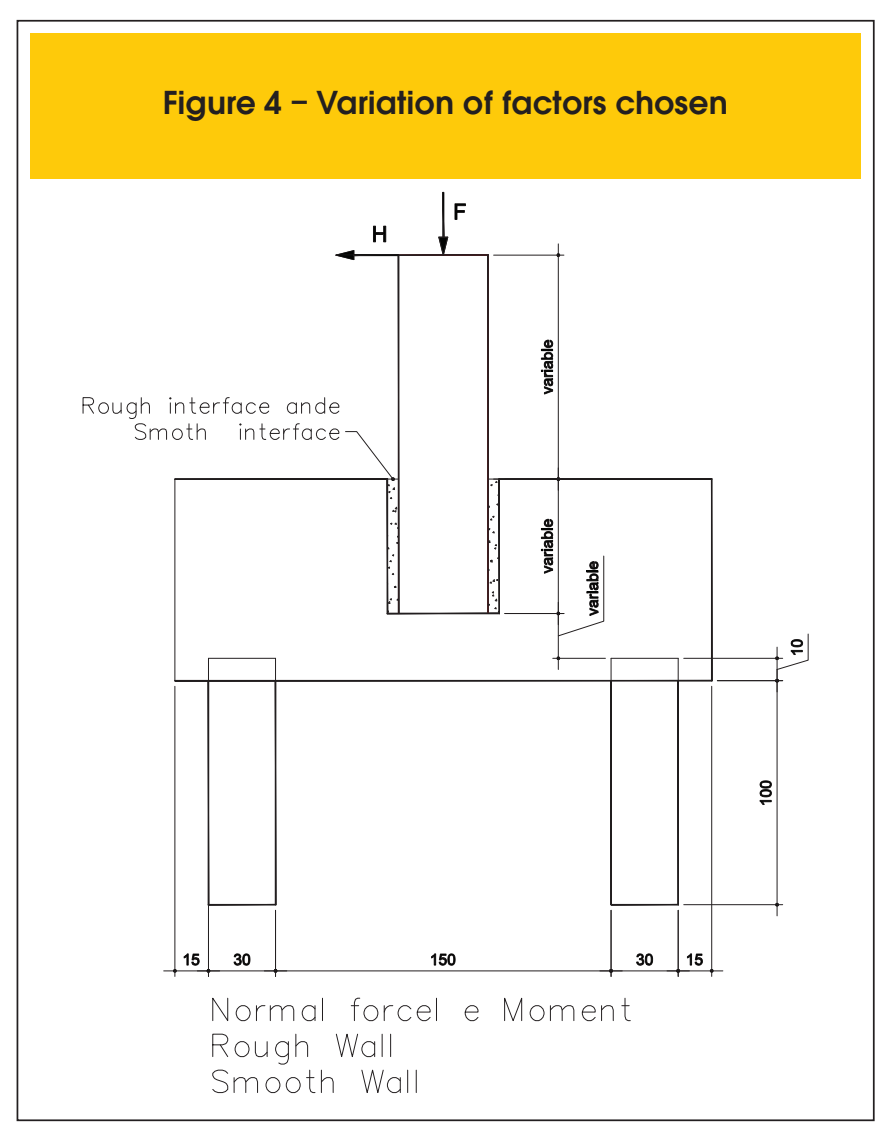


Table 1 - Pile caps properties analyzed for smooth and rough walls

\begin{tabular}{|c|c|c|c|c|c|c|c|c|c|}
\hline Pile caps & $\begin{array}{c}\text { Total } \\
\text { heigth } \\
\text { h (cm) }\end{array}$ & $\begin{array}{l}\text { Measure the } \\
\text { sides of } \\
\text { the column } \\
(\mathrm{cm})\end{array}$ & $\begin{array}{l}\text { Measure the } \\
\text { sides of } \\
\text { the piles } \\
(\mathrm{cm})\end{array}$ & $\begin{array}{c}A_{\text {st }} \\
\left(\mathrm{cm}^{2}\right)\end{array}$ & $\begin{array}{c}B_{1 x} \\
(\mathrm{~cm})\end{array}$ & $\begin{array}{c}\mathrm{B}_{\mathrm{ly}} \\
(\mathrm{cm})\end{array}$ & $\begin{array}{l}\ell_{\mathrm{emb}} \\
(\mathrm{cm})\end{array}$ & $\begin{array}{c}h_{\mathrm{s}} \\
(\mathrm{cm})\end{array}$ & $\begin{array}{c}\text { Classification ABNT } \\
\text { NBR 6118:2007 }\end{array}$ \\
\hline 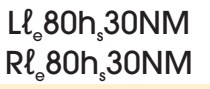 & 110 & $40 \times 40$ & $30 \times 30$ & 22 & 240 & 84 & 80 & 30 & Rigid \\
\hline $\begin{array}{l}\mathrm{Ll}_{\mathrm{e}} 80 \mathrm{~h}_{\mathrm{s}} 20 \mathrm{NM} \\
\mathrm{Rl}_{\mathrm{e}} 80 \mathrm{~h}_{\mathrm{s}} 20 \mathrm{NM}\end{array}$ & 100 & $40 \times 40$ & $30 \times 30$ & 22 & 240 & 84 & 80 & 20 & Rigid \\
\hline $\begin{array}{l}\mathrm{Ll}_{\mathrm{e}} 80 \mathrm{~h}_{\mathrm{s}} 10 \mathrm{NM} \\
\mathrm{Rl}_{\ominus} 80 \mathrm{~h}_{\mathrm{s}} 10 \mathrm{NM}\end{array}$ & 90 & $40 \times 40$ & $30 \times 30$ & 22 & 240 & 84 & 80 & 10 & Rigid \\
\hline $\begin{array}{l}\mathrm{Ll}_{e} 60 \mathrm{~h}_{\mathrm{s}} 30 \mathrm{NM} \\
\mathrm{Rl}_{\mathrm{e}} 60 \mathrm{~h}_{\mathrm{s}} 30 \mathrm{NM}\end{array}$ & 90 & $40 \times 40$ & $30 \times 30$ & 22 & 240 & 84 & 60 & 30 & Rigid \\
\hline $\begin{array}{l}\mathrm{Ll} \ell_{\mathrm{e}} 60 \mathrm{~h}_{\mathrm{s}} 20 \mathrm{NM} \\
\mathrm{R} \ell_{\mathrm{e}} 60 \mathrm{~h}_{\mathrm{s}} 20 \mathrm{NM}\end{array}$ & 80 & $40 \times 40$ & $30 \times 30$ & 22 & 240 & 84 & 60 & 20 & Rigid \\
\hline 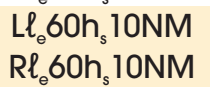 & 70 & $40 \times 40$ & $30 \times 30$ & 22 & 240 & 84 & 60 & 10 & Rigid \\
\hline $\begin{array}{l}\mathrm{Ll} \ell_{\mathrm{e}} 50 \mathrm{~h}_{\mathrm{s}} 30 \mathrm{NM} \\
\mathrm{Rl} 50 \mathrm{~h}_{\mathrm{s}} 30 \mathrm{NM}\end{array}$ & 80 & $40 \times 40$ & $30 \times 30$ & 22 & 240 & 84 & 50 & 30 & Rigid \\
\hline $\begin{array}{l}\mathrm{Ll} \ell_{\mathrm{e}} 50 \mathrm{~h}_{\mathrm{s}} 20 \mathrm{NM} \\
\mathrm{Rl} 50 \mathrm{~h}_{\mathrm{s}} 20 \mathrm{NM}\end{array}$ & 70 & $40 \times 40$ & $30 \times 30$ & 22 & 240 & 84 & 50 & 20 & Rigid \\
\hline $\begin{array}{l}\mathrm{Ll}_{\mathrm{e}} 50 \mathrm{~h}_{\mathrm{s}} 10 \mathrm{NM} \\
\mathrm{R} \ell_{\mathrm{e}} 50 \mathrm{~h}_{\mathrm{s}} 10 \mathrm{NM}\end{array}$ & 60 & $40 \times 40$ & $30 \times 30$ & 22 & 240 & 84 & 50 & 10 & Rigid \\
\hline
\end{tabular}

crushing occurs when all compression tensions reach the rupture superficies, subsequently, the elasticity module has value equal to zero in all directions. Figure [7] presents the element Solid 65.

In the modeling of the steel bars of the reinforcement it was used the finite element Link 8. This element has two nodes, so that each node has three degrees of freedom - translations in the directions $x, y$ and $z$. Figure [8] shows this element. We chose this element, because the armors in the models were discrete.

In the models, it was not considered the phenomenon of the adherence between the steel bars and the concrete. In spite, the results

Figure 5 - Discretization used in the models 
Figure 6 - Boundary conditions and finite element

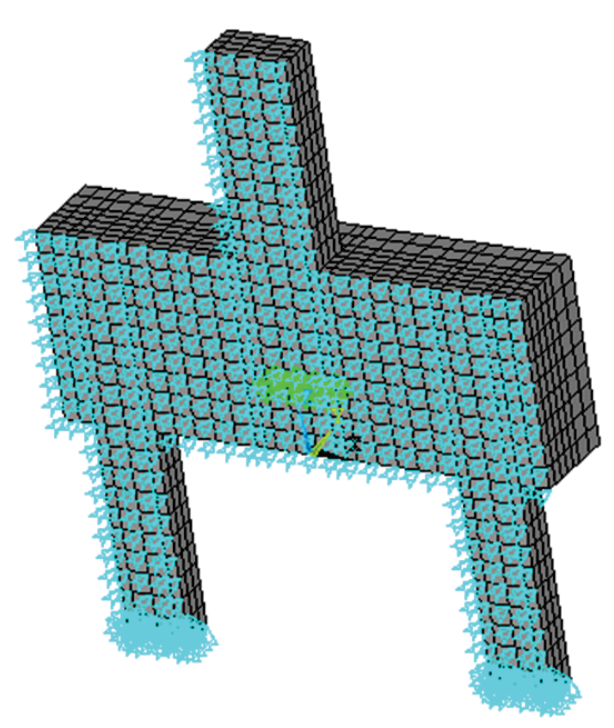

of the comparisons among experimental and numerical results were satisfactory, as presented in the item 3.3.

To represent the friction between the walls of the precast and the filling material (grout) and the faces of the precast column, elements of contact were used, being definite contact superficies between the materials (contact superficies and target superficies). The contact superficies between the materials were represented by tow finite elements, named "contact pair". For the contact superficies, the finite element Contact 173 was used and for the target superficies, the finite element Target 170 was used. These elements have three freedom degrees in each node and the geometric properties are the same as in the faces of the solid elements to which they are linked, which may have triangular or quadrangular geometry. Figure [9] presents the contact pairs (element Contact 173 and Target 170).

Figure 7 - Solid 65 , Ansys ${ }^{\circledR}$

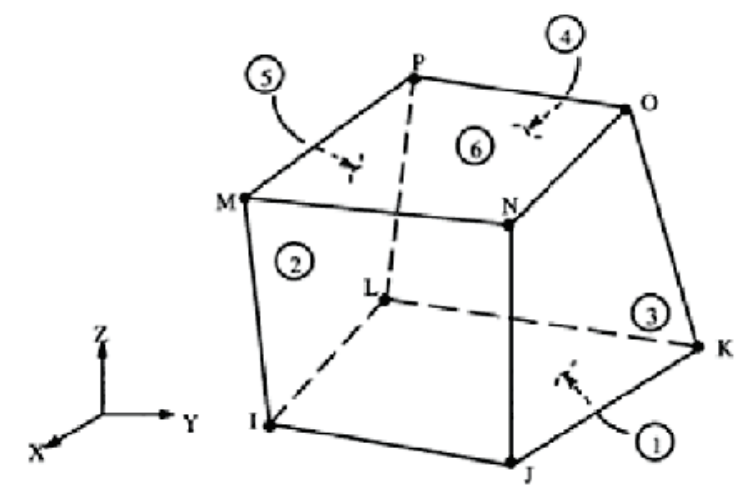

Figure 8 - Link 8 , Ansys ${ }^{\circledR}$

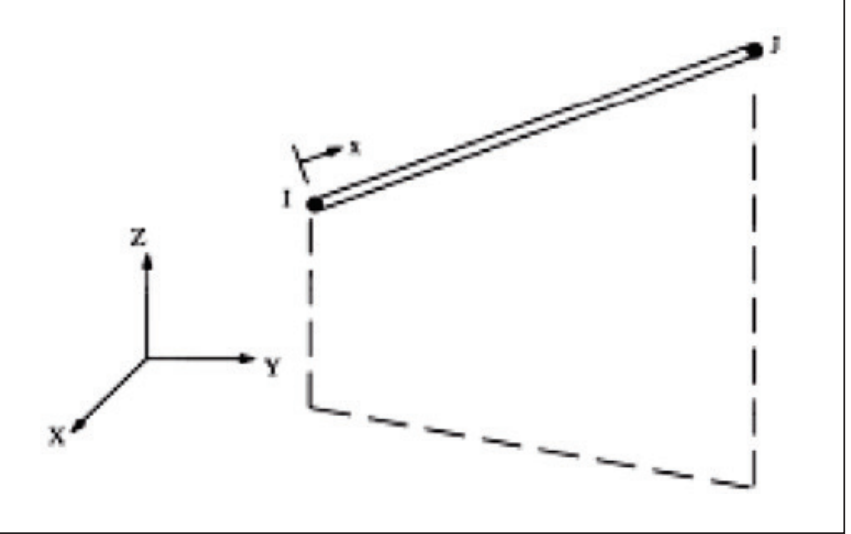

The finite elements of contact were used only in the models with smooth conformation of the walls of the precast and the column, because, due to researches already performed by several researchers, it can be considered that the link column-foundation through precast with shear key have monolithic behavior.

\subsection{Materials properties}

Developing a model able to represent the concrete behavior as close as the real behavior is a challenge. The reinforced concrete is an almost fragile material and has different behaviors in the compression and in the traction.

In the compression, the curve tension vs. deformation of the concrete is elastic and linear until nearly $30 \%$ of the last compression force. After this point, the concrete loses rigidity and follows elevating the tension values until rupture force. Thereafter, there is no increase of the tension suffering softening. In the traction, the curve tension vs. deformation of the concrete is nearly elastic and linear until the tension of the maximal traction. After this point, the concrete cracks and its strength is not considering the softening in the traction.

To model the concrete material, it is necessary to provide the program Ansys ${ }^{\circledast}[23]$ the following input data: longitudinal elasticity module of the concrete; ultimate strength of the concrete to compression and traction; Poisson coefficient; and transfer coefficient of shear. Ansys ${ }^{\circledR}[23]$ also allows as input data, the inclusion of a tension stress vs. deformation to represent the mechanical properties of concrete. This is normally done, when by convergence problems, the processing is abruptly interrupted by early crushing of the concrete. Kachlakev et al. [9] bring bigger information on this phenomenon. In the analyzed models, this problem did not occur. The longitudinal elasticity module of the concrete, $E_{c}$, as well as, the concrete traction strength, $\mathrm{f}_{\mathrm{tk}}$, were determined based in the recommendations of NBR 6118:2007 [1]. Poisson coefficient, $v$, adopted to the concrete was equal to 0.2 and the shear transference coefficients, $\beta$ adopted were equal to 1 to open and closed cracking. This value for the coefficient $\beta$ was used, because tests performed showed bigger efficiency in the convergence of the processing when used the mentioned value, see Delalibera [5]. Concrete rupture criterion provided by Ansys ${ }^{\circledR}$ was used. For the 


\section{Figure 9 - Finite Element Contact, Ansys ${ }^{\circledR}$}

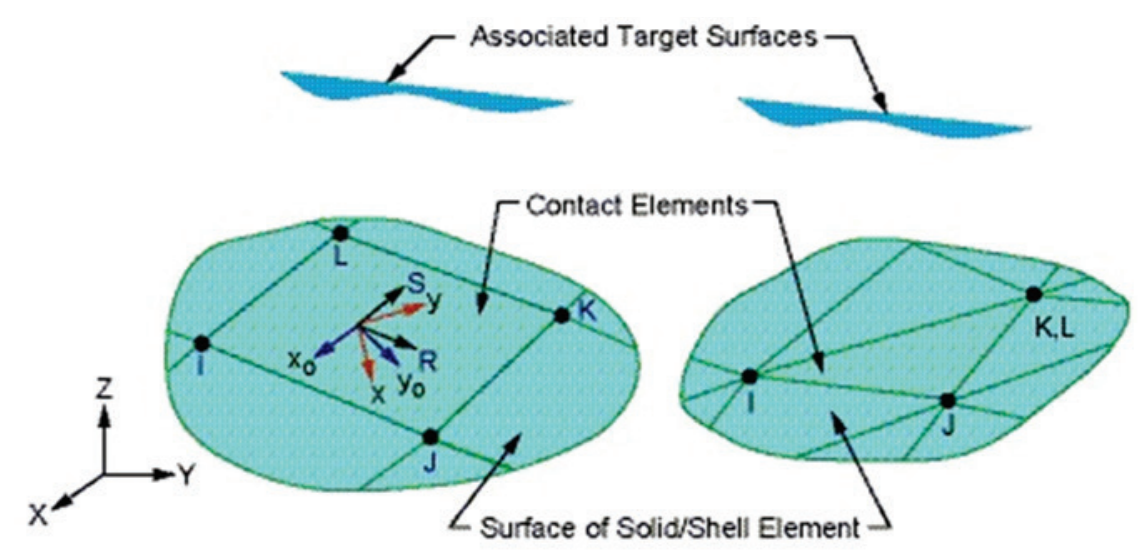

definition of the rupture superficies it is necessary only two parameters: the strengths to the last compression and traction of the concrete. Concrete rupture criterion is analogue to William-Warnke rupture criterion. Figure [10] presents the rupture superficies.

In all pile caps was adopted compressive strength of concrete $\left(f_{c k}\right)$ equal to $25 \mathrm{MPa}$.

For the steel bars, it was adopted perfect elastic-plastic behavior. The elasticity module used was equal to $210 \mathrm{GPa}$, Poisson coefficient equal to 0.3 and the tension steel equal to $500 \mathrm{MPa}$.

Through the tests performed, we verified that Newton-Raphson criterion was the one which presented the best results regarding

\section{Figure 10 - Failure Surface in Principal Stress Space, Concrete, Ansys ${ }^{\circledR}$}

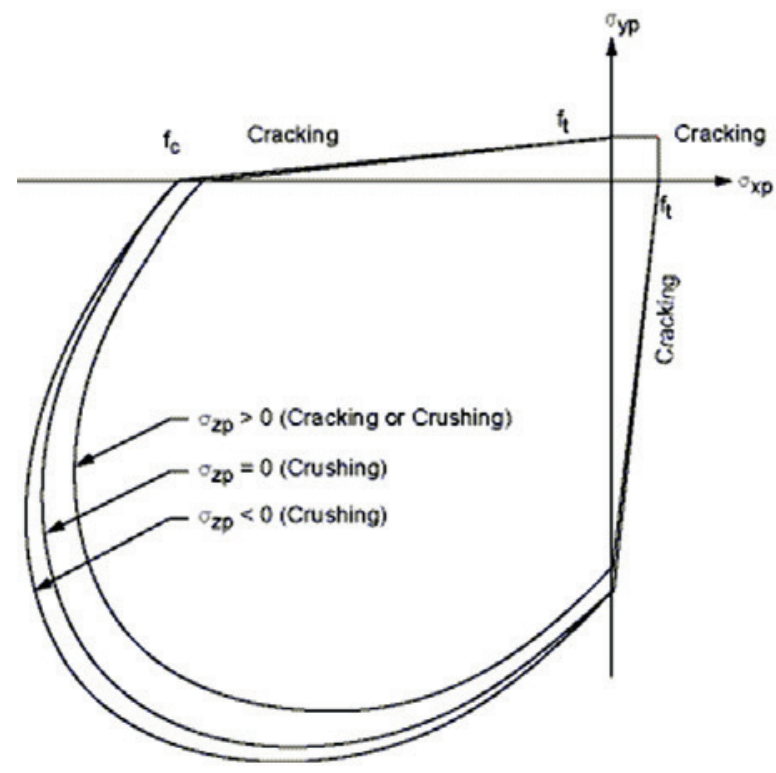

the convergence of the models, thus, in all analyses this criterion was used.

For the properties of the contact elements, it was used the Coulomb friction model, being necessary to define the value of the friction coefficient, $\mu$, the maximal shear stress, $\tau_{\text {maximum }}$ and two constants, FKN and FTOLN, FKN represent a normal rigidity coefficient of the contact element and FTOLN constant is a tolerance factor to be applied in the sense of the normal vector of the superficies. This factor is used to determine the penetration compatibility. The contact compatibility is satisfied if the penetration is in permissible tolerance (FTOLN measures the deepness of the underlying elements). The deepness is definite by the average deepness of each individual element of the contact in the pair. If the computer program Ansys $₫[23]$ detects any penetration bigger than this tolerance, the global solution does not converge, even if the residual forces and the displacement increments are found in the criteria of the adopted convergence. For FKN coefficient we used value equal to 1 and for FTOL value equal to 0.1 .

The choice of the "correct" value of the friction coefficient is a hard task, as it depends on several factors: type of superficies, intensity of actions, mechanic properties of the materials which compose the link column-foundation. There are, in the technical literatures several indications for the value of the friction coefficient concreteconcrete. According to Nielsen [10] the value to be used is 0.6, EN 1992-1-1 [03] indicates that the friction coefficient value for the situation where the link column-foundation by half precast with smooth walls, must be higher than 0,3. Canha [11] and Ebeling [12] analyzed the influence of the friction coefficient in links columnfoundation by half precast, varying the value of $0.60,0.45$ and 0.30 . Osani et al. [13] suggests that the values of friction coefficient have values equal to 0,5 and 1 , function of the embed length and of the king of the precast and column walls conformation. In this work, suggesting the recommendations of Canha \& El Debs [14] used the friction coefficient equal to 0,6 . It is important to remember that this numerical analysis aims at presenting the behavior trend of the link column-foundation behavior through embed precast in blocks on two piles, with main end of analyzing the relevance of the analyzed factors. 
In relation to the shear tension, $\tau_{\text {maximum, }}$, we adopted the value used by the computer program, $\left[\sigma_{y} /\left(3^{1 / 2}\right)\right]$, in which $\sigma y$ is the strength to the outflow of the rupture criterion of Von Mises, of the underlying material to the contact superficies. For $\sigma_{y}$ we used values indicated by Canha [11], where this tension values thirty per cent of the compressive strength of concrete of minor strength belonging to the contact. Therefore, $\sigma_{y}$ value adopted was equal to $7.5 \mathrm{MPa}$, resulting 2.5 MPa for the value of $\tau$

\subsection{Comparative analysis}

In order to verify if the adopted models for the numerical analysis of the two pile caps show correct behavior trend, comparative analysis of experimental tests and numerical simulations of severa researchers. In this work, it will be presented the results of the comparative numerical analyses of the tests performed by Mautoni [15] and Adebar et al. [16] and of the numerical simulation developed by Sam \& Iyer [17]. In Delalibera [5], it can be observed the rest of the comparative analyses performed and more details of the numerical analyses developed.

In the comparative analysis, we also used the same finite elements used in the analyses of the two pile caps, i.e., Solid 65 - discretizing the concrete material and Link 8 - modeling the steel bars. All mechanic and geometric properties adopted in the comparative analysis were the same as in the experimental tests. The contour conditions used in the tests with higher possible reality degree, the same thing happening to the loading.

The first comparative analysis is of the pile cap B1-A tested by Mautoni [15]. The pile cap had rupture by shear with last force equal to $800 \mathrm{kN}$. The first crack appeared with nearly thirty per cent of the last force, about $240 \mathrm{kN}$. The pile caps was twenty five centimeters high, the column was squared with a $225 \mathrm{~cm}^{2}$ area and the piles had transversal sections equal to $10 \mathrm{~cm} \times 15 \mathrm{~cm}$. The compressive strength of concrete was equal to $32.30 \mathrm{MPa}$ and the steel bars of the tie presented strength of equal to $720 \mathrm{MPa}$. As there was no information on the elasticity module and on steel and concrete Poisson coefficients, we adopted the recommendations of NBR 6118:2007 [1].
We applied the numerical model three hundred force increments, whereas to each increment the applied force value was $2,67 \mathrm{kN}$. Figure [11] shows the final configuration obtained in the experiment and in the simulation of the block B1-A.

The force value which originated the first crack in the numerical model was $312,33 \mathrm{kN}$. It occurred difference of $23.15 \%$ in relation to the force value which originated the first crack in the experimental model. It occurred because in the experimental model, the force that provoked the first crack was determined as a function of visual observation, i.e, the first crack visible to the human eye. In relation to the last force, the numerical model presented last force of $799,98 \mathrm{kN}$, practically, did not occur difference with the value experimentally obtained.

The second comparative analysis is two blocks tested by Adebar et al. [16]. Pile caps A, B, C, D and F were simulated. All pile caps were sixty centimeters tall and Poisson coefficients equal to 0,3 and 0,2 for steel and concrete respectively. In all pile five hundred force increments were applied.

Pile cap A was constituted by four piles of twenty centimeters and column with squared transversal section with thirty centimeters side. The average compressive strength of concrete $\left(f_{\mathrm{cm}}\right)$ obtained in the tests was equal to $27,10 \mathrm{MPa}$. The steel bars had tensile strength equal to $479 \mathrm{MPa}$. In the test, the first crack emerged with force equal to $1186 \mathrm{kN}$ and the rupture force was equal to $1781 \mathrm{kN}$. In the numerical model, the first crack occurred with force equal to 1403,86 and the ruin force obtained was equal to $1781,10 \mathrm{kN}$. Pile cap B had the same geometric properties of Pile cap A, however, the reinforcement was distributed on piles, while in Pile A, the reinforcement was distributed in mesh. The compressive strength of concrete was $24,80 \mathrm{MPa}$ and the tensile strength the steel bars of the tie was the same as in Pile cap A. In the test, the first crack emerged for a $1679 \mathrm{kN}$ force, now, in the numerical model, the first crack occurred with $1505,71 \mathrm{kN}$. The experimental ruin force was registered with value equal to $2189 \mathrm{kN}$ and in the numerical simulation, the force obtained was $2186 \mathrm{kN}$.

Pile cap $\mathrm{C}$ had six piles with diameters of twenty centimeters and column with the same transversal section of the other models. The

Figure 11 - Final configuration of the pile cap B1-A, tested by Mautoni (1972)

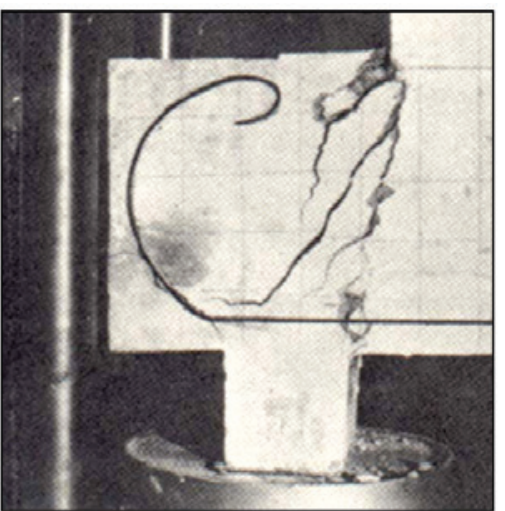

Experimental.

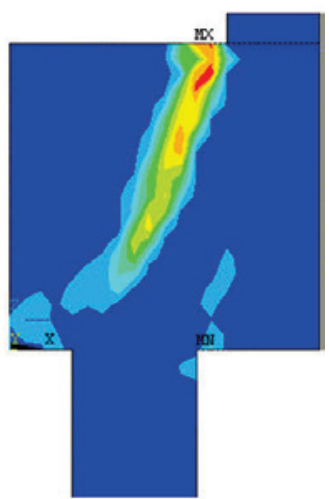

Numerical. 
Figure 12 - Pile cap A, Adebar et al. (7)

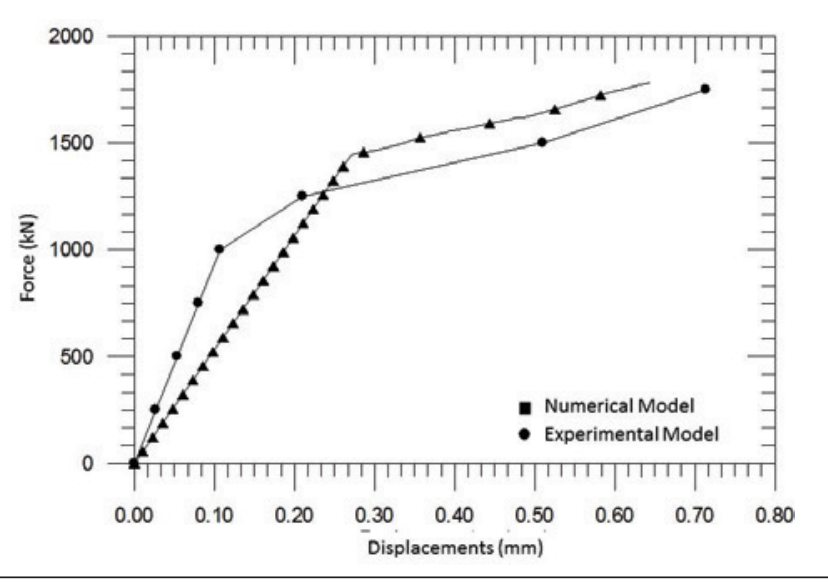

Figure 13 - Pile cap B, Adebar et al. (7)

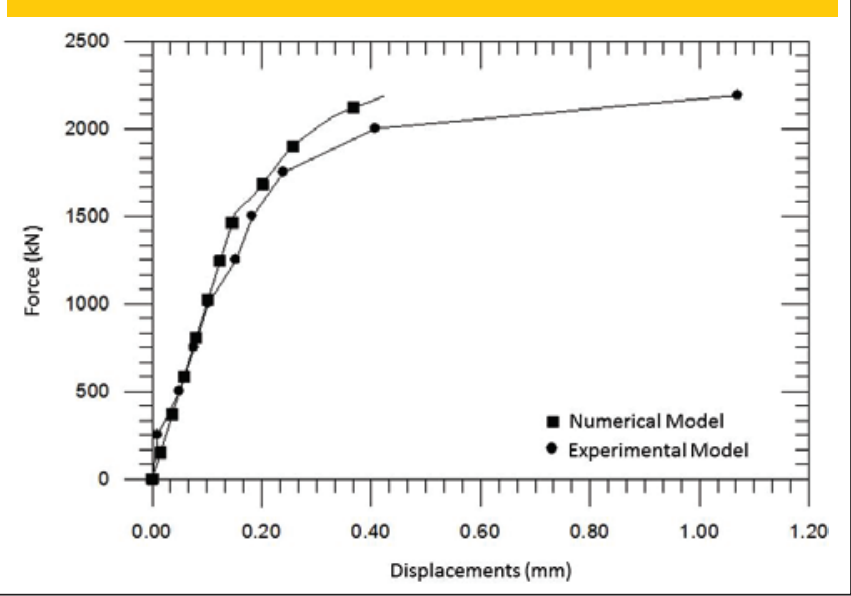

Figure 14 - Pile cap C, Adebar et al. (7)

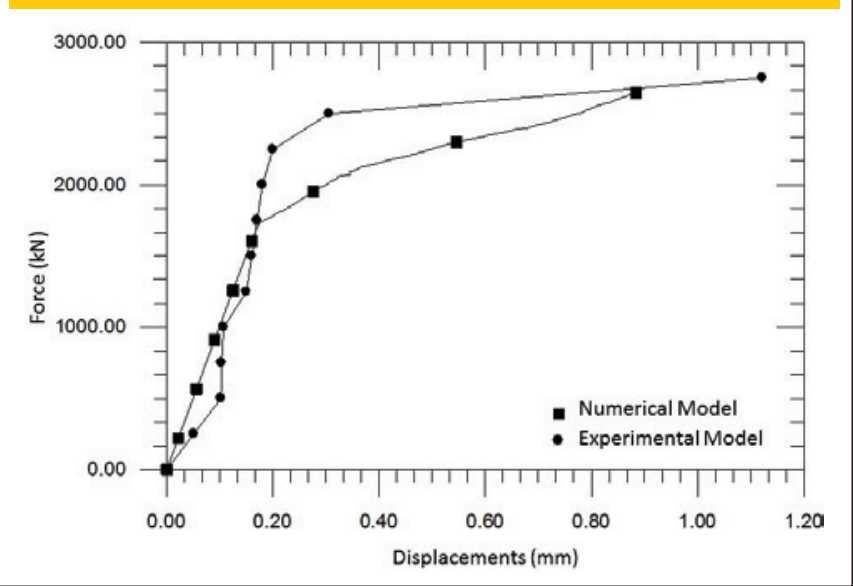

average compressive strength of concrete was $27.10 \mathrm{MPa}$ while the tensile strength the tie was equal $479 \mathrm{MPa}$. The first crack in the test emerged to a force of $1780 \mathrm{kN}$ and the rupture force observed was $2892 \mathrm{kN}$. In the numerical model these forces were $1588.30 \mathrm{kN}$ and $2647.70 \mathrm{kN}$ respectively.

Pile cap D was similar to Block B, changing only the area of the steel bars of the reinforcement. The compressive strength of concrete was equal to $30.30 \mathrm{MPa}$ and the tensile strength of the bars was equal to $486 \mathrm{MPa}$. The first crack presented for the force of 1122 $\mathrm{kN}$ and the pile cap rupture occurred for the force of $3222 \mathrm{kN}$. In the numerical simulation, the force that originated the first crack was $1097.74 \mathrm{kN}$ and the ruin force observed was $3212.17 \mathrm{kN}$. In spite of obtaining good correlation between the cracking and last forces, the numerical simulation presented substantial differences in relation to the rigidity of Pile cap $D$ experimentally tested, see Figure [15].

Pile cap F had the same mechanical properties of Pile cap B, however, changed only its geometric form. The force that provoked the

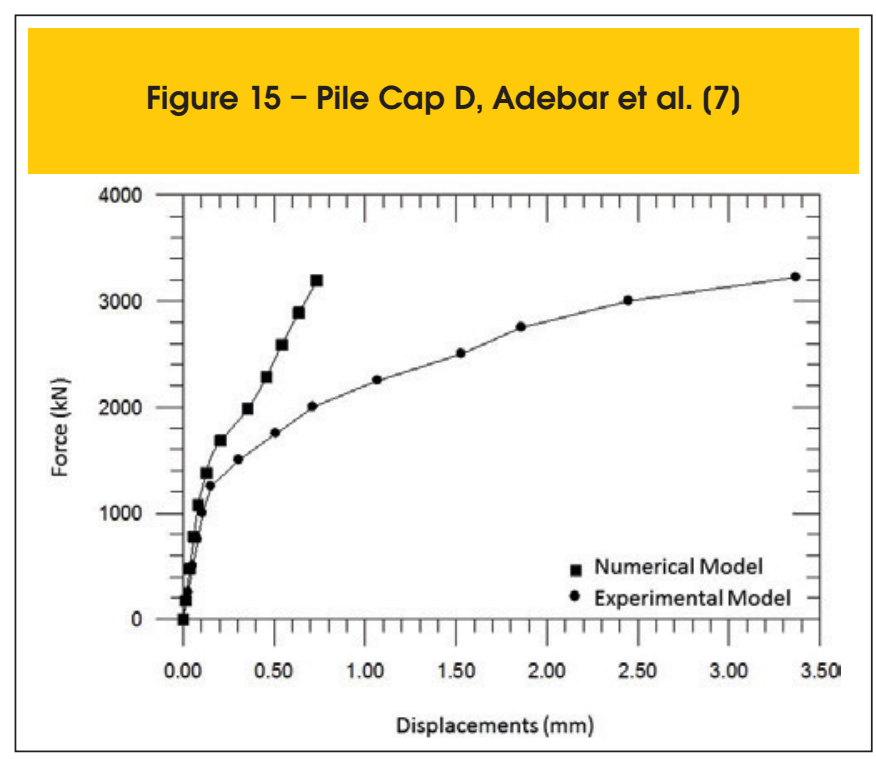

Figure 16 - Pile Cap F, Adebar et al. (7)

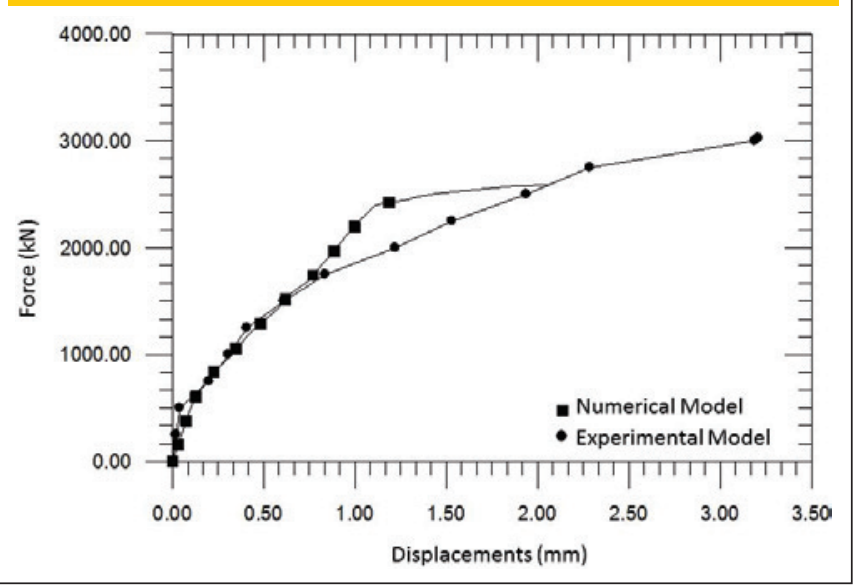


Table 2 - Relations between numerical results and experimental pile caps tested by Adebar et al. (7)

\begin{tabular}{|cccc|}
\hline Pile caps & $\mathrm{F}_{\text {u,exp }}(\mathrm{kN})$ & $\mathrm{F}_{\text {unum }}(\mathrm{kN})$ & $\mathrm{F}_{\text {u,exp }} / \mathrm{F}_{\text {unum }}$ \\
\hline Bloco A & 1781 & 1781,10 & 0,99 \\
Bloco B & 2189 & 2186 & 1,00 \\
Bloco C & 2892 & 2647,7 & 1,09 \\
Bloco D & 3222 & 3212,70 & 1,01 \\
Bloco F & 3026 & 2589,74 & 1,17 \\
\hline
\end{tabular}

first crack was equal to $650 \mathrm{kN}$ and the rupture force observed was equal to $3026 \mathrm{kN}$. In the numerical simulation, these forces were $501,94 \mathrm{kN}$ and $2589.74 \mathrm{kN}$.

Figures [12], [13], [14], [15] e [16] showed the correlations obtained between the numerical and experimental results and Table [2] relations between the last experimental and numerical forces.

The third comparative analysis refers to the blocks numerically simulated by lyer \& Sam [17]. The piles caps were simulated with arrangement reinforcement distributed in mesh and on the piles.

The pile cap were twenty-two centimeters and five millimeters of height and were composed by four piles with square transversal section of $10 \mathrm{~cm} \times 10 \mathrm{~cm}$. The columns also had squared section with $14.14 \mathrm{~cm} \times 14.14 \mathrm{~cm}$ side. The compressive strength of concrete was equal to $19 \mathrm{MPa}$ and the tensile strength of the steel bars equal to $300 \mathrm{MPa}$. Poisson coefficient adopted to steel and concrete was 0.3 and 0.2 respectively. In the numerical simulations were adopted 345 force increments. The last forces obtained in the analyses developed by lyer \& Sam (1995) were: $600 \mathrm{kN}$, for reinforced on mesh and $560 \mathrm{kN}$, for reinforced on piles. In the numerical simulation developed in this text, the forces found were: $582.17 \mathrm{kN}$ for the pile cap with reinforcement arrangement distributed on mesh and $594.59 \mathrm{kN}$ for the pile caps with reinforcement arrangement distributed on piles. Figures [17] and [18] presented the correlations among the results obtained.

\section{Figure 17 - Main reinforcement mesh, Sam \& lyer (17)}

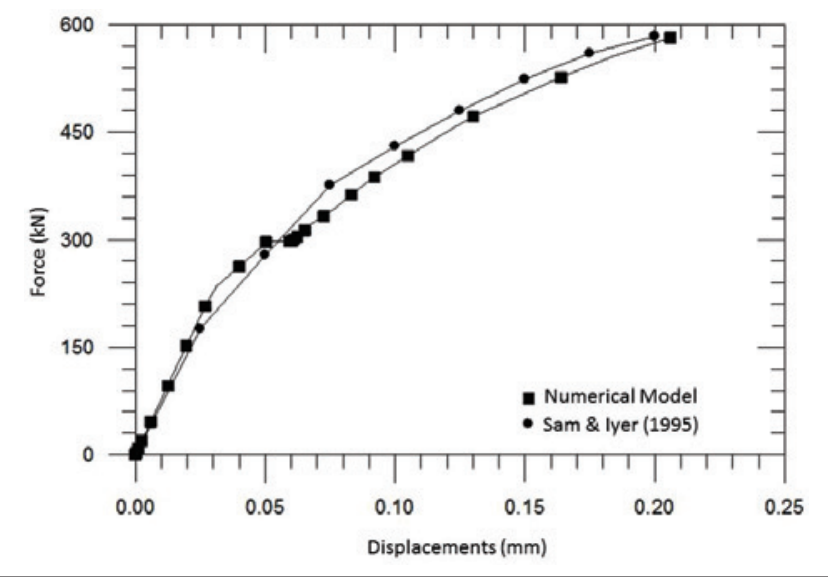

\section{Figure 18 - Reinforcement distributed over the piles, Sam \& lyer (17)}

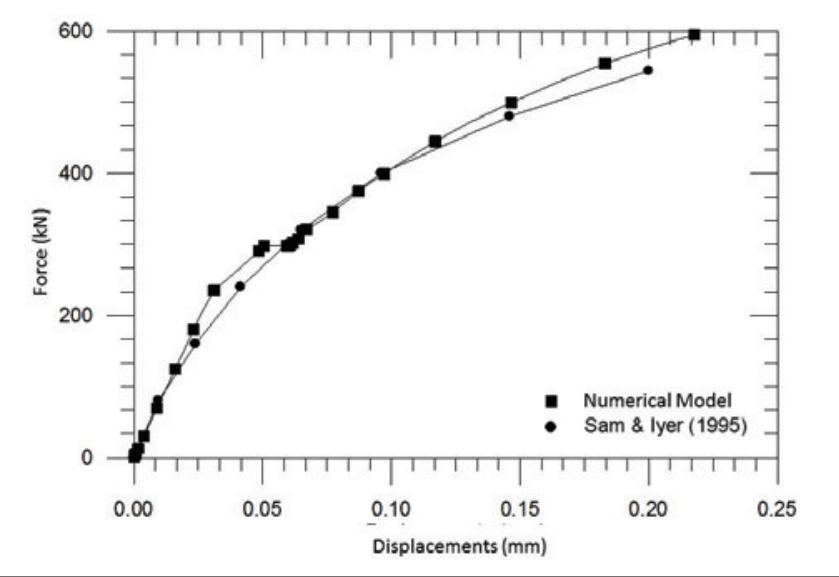

We observe in Figures [17] and [18] that there is great correlation among the results, indicating that the model adopted in the numerical analysis is consistent.

\subsection{Influence of the length of the pile and the soil}

As the experimental test of the pile caps with real length piles are of difficult execution, we simulated pile caps with real length piles, aiming to observe the behavior of the main stress outflow of compression and the length influence of the piles on the block. Thereunto, four pile caps were modeled - three with piles with real lengths and

Figure 19 - Result of SPT, Senna Júnior (18)

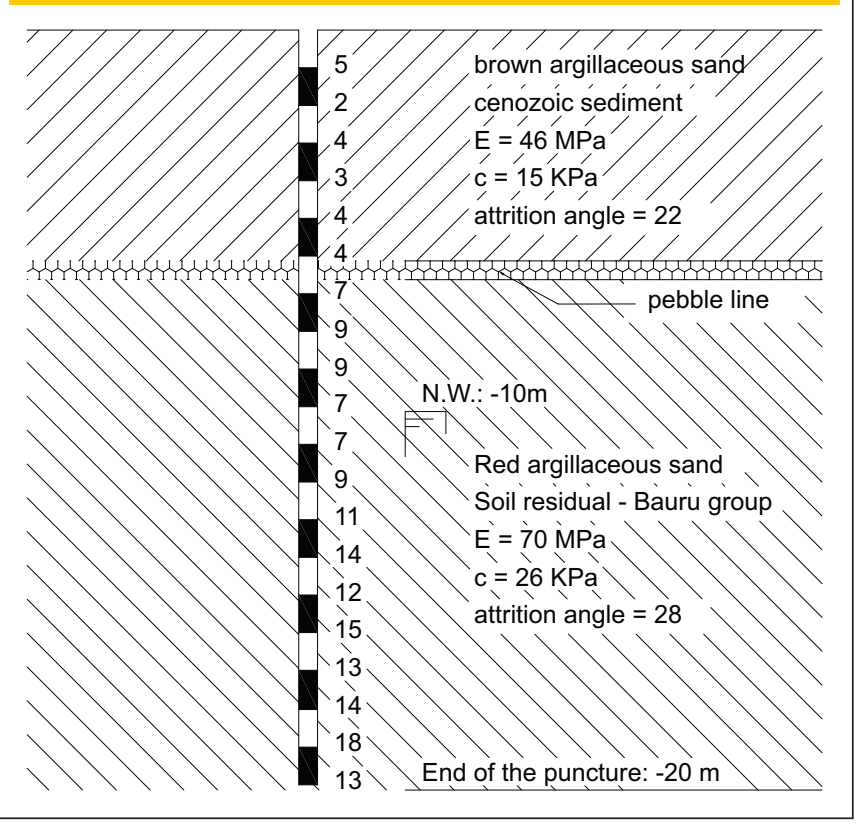




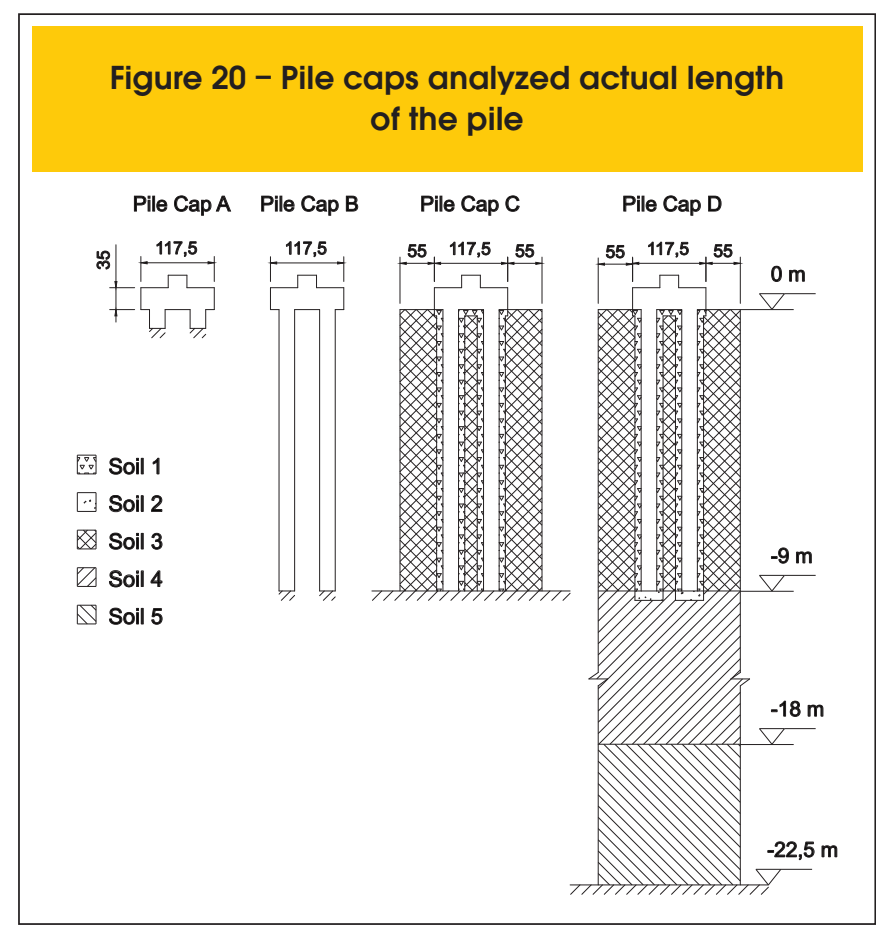

one with small height piles. In the model was used one pile cap on two piles with angle of inclination of the strut equal to $45^{\circ}$. The length of the piles was determined according to the result of the survey executed by Geotechnical Department, in Campus I of USP in São Carlos. Thus, the length calculated of the piles shaft was equal to 9.0 $\mathrm{m}$. Figure [19] shows the result of the survey the percussion (S.P.T.) and Figure [20] the pile caps numerically analyzed.

The friction between the pile and the soil was not taken into account. For the existing soil around the pile shaft, we adopted a plastic behavior (rupture criterion Drucker-Prager). The result of the survey the percussion and mechanical properties of the soil were obtained in Senna Júnior [18]. The force was applied through

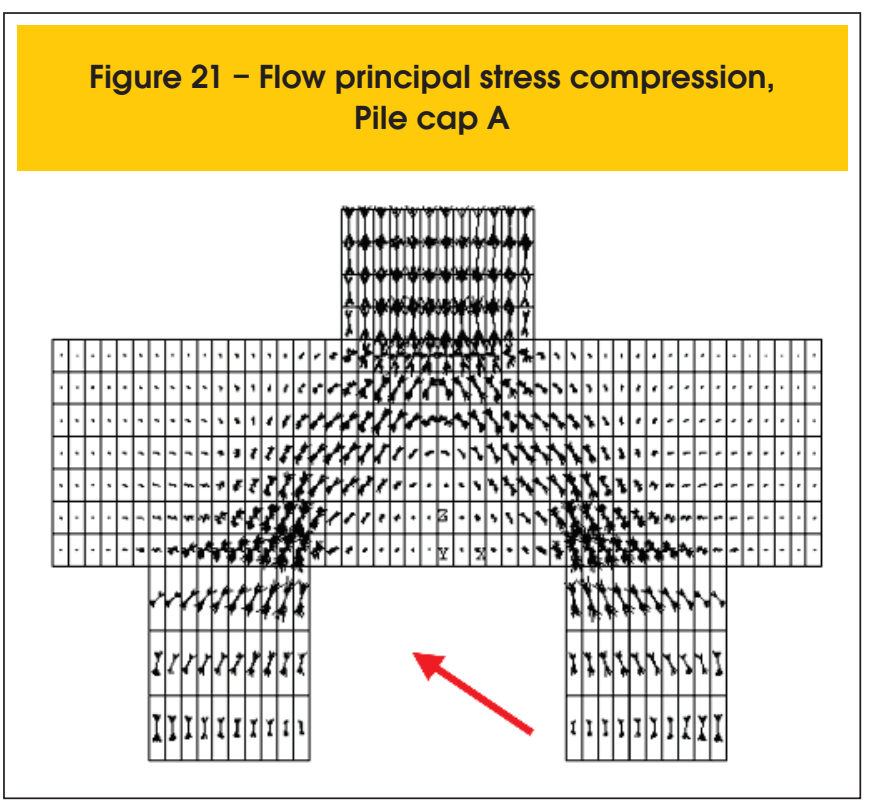

Figure 22 - Flow principal stress compression, Pile cap B

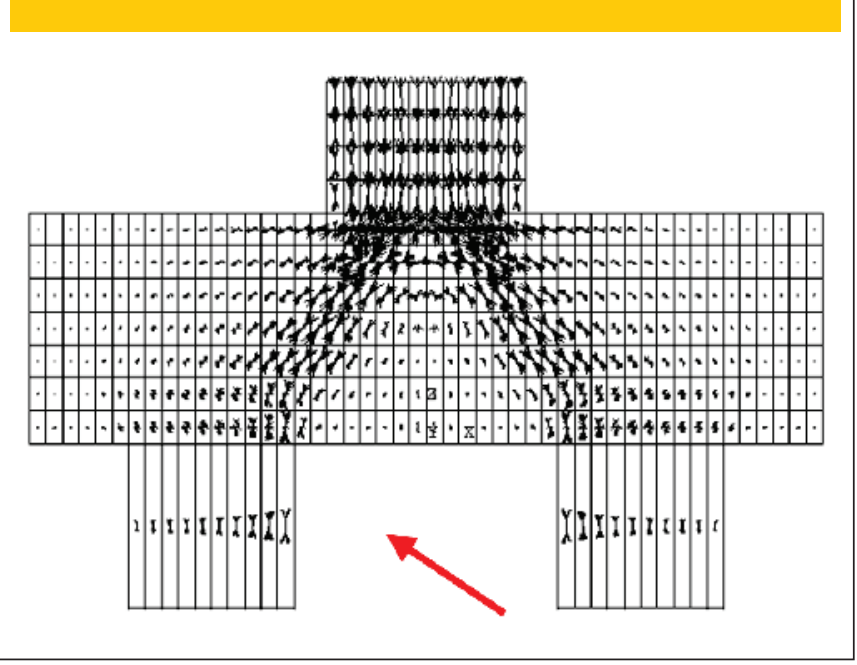

one hundred steps, admitting it centered. In the models where there was no contribution of the soil (Pile caps A and B - Figure [20], it applied force until the pile cap rupture. In the other models, the action applied corresponded to the piles loading capacity, i.e., $600 \mathrm{kN}$.

In the soil modeling, we used the model of elastic Continuum model (Soil 1, 4 and 5 - Figure [20]). The soil could be modeled using Winkler hypotheses (contact pressures are proportional to settlements), however, according to Velloso [19], the Medium Continuum model represents with higher accuracy the phenomenon of the interaction soil-structure.

To avoid localized disturbance stress on the force application point, it was modeled a steel plate on the head of the column five centimeters thick and elastic and linear material, the same for all the numerical analysis developed.

\section{Figure 23 - Flow principal stress compression, Pile cap C}

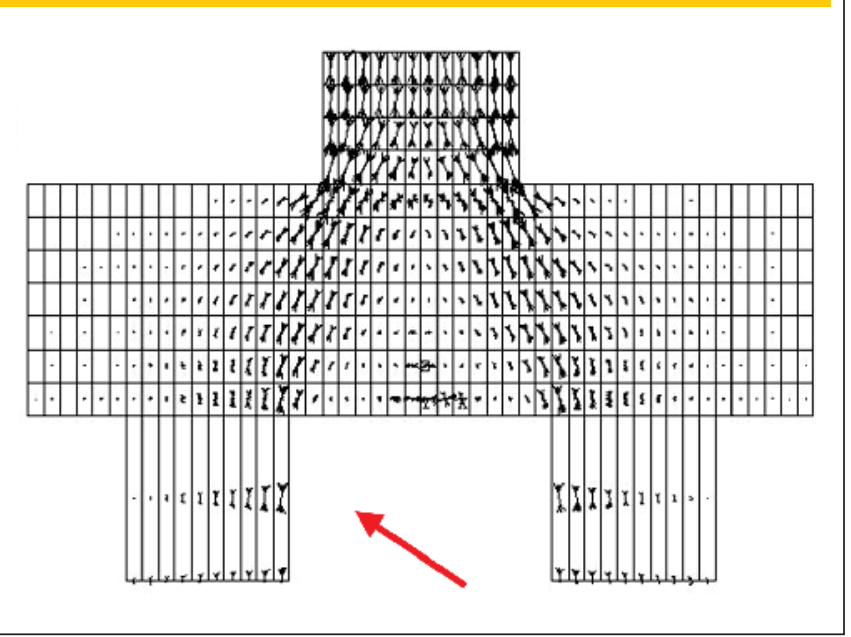


As it was intended to analyze the behavior of the pile caps, it was adopted in the piles and in the columns, compressive strength of concrete equal to $50 \mathrm{MPa}$. The coefficients of shear transference also had value equal to 1 . The elasticity model of the steel and concrete, as well as their respective Poisson coefficients, were determined with recommendations of NBR 6118:2007 [1]. The reinforcement rates were equal in all models, whereas, the areas of reinforcement of piles, of columns and ties are presented in Table [3]. For more information, see Delalibera [5].

By Figures [21] to [24], it can be observed that there is more concentration of compression stress in the pile caps sections just below the column and in the section of the piles farther from the pile cap board, sections F and G - Figure [20]. It was verified that the piles not requested uniformly, i.e., the sections farther from the pile

Table 3 - Criteria used in the pile cap modeling, considering the influence of the piles and soil

\begin{tabular}{|c|c|c|c|c|}
\hline Estructural element & Finite element & Real constants & Material properties & Additional informaticon \\
\hline Column & Solid 65 & - & $\begin{array}{c}\mathrm{E}_{\mathrm{c}}=33658 \mathrm{MPa} \\
v=0,3 \\
\mathrm{f}_{\mathrm{ck}}=50 \mathrm{MPa} \\
\mathrm{f}_{\mathrm{tk}}=4,07 \mathrm{MPa} \\
\beta=1\end{array}$ & Plastic behavior - concrete \\
\hline Pile caps & Solid 65 & - & $\begin{array}{c}\mathrm{E}_{\mathrm{c}}=21287 \mathrm{MPa} \\
v=0,3 \\
\mathrm{f}_{\mathrm{ck}}=20 \mathrm{MPa} \\
\mathrm{f}_{\mathrm{tk}}=2,21 \mathrm{MPa} \\
\beta=1\end{array}$ & Plastic behavior - concrete \\
\hline Piles & Solid 65 & - & $\begin{array}{c}\mathrm{E}_{\mathrm{c}}=33658 \mathrm{MPa} \\
v=0,3 \\
\mathrm{f}_{\mathrm{ck}}=50 \mathrm{MPa} \\
\mathrm{f}_{\mathrm{tk}}=4,07 \mathrm{MPa} \\
\beta=1\end{array}$ & Plastic behavior - concrete \\
\hline$A_{s, \text { trinante }}$ & Link 8 & $A_{s}=3,15 \mathrm{~cm}^{2} \quad \varepsilon_{i}=0$ & $\begin{array}{c}E_{s}=210 \mathrm{MPa} \\
\mathrm{f}_{\mathrm{y}}=500 \mathrm{MPa} \\
v=0,3\end{array}$ & Elastic-plastic perfect behavior \\
\hline$A_{s, \text { pilar e estacas }}$ & Link 8 & $A_{s}=1,25 \mathrm{~cm}^{2} \quad \varepsilon_{i}=0$ & $\begin{array}{c}E_{s}=210 \mathrm{MPa} \\
\mathrm{f}_{\mathrm{y}}=500 \mathrm{MPa} \\
v=0,3\end{array}$ & Elastic-plastic perfect behavior \\
\hline Steel plate & Solid 65 & - & $\begin{array}{c}\mathrm{E}_{\mathrm{s}}=210 \mathrm{MPa} \\
\mathrm{v}=0,3\end{array}$ & Elastic-plastic perfect behavior \\
\hline Stirrups & Link 8 & $A_{s}=0,50 \mathrm{~cm}^{2} \quad \varepsilon_{i}=0$ & $\begin{array}{c}E_{s}=210 \mathrm{MPa} \\
\mathrm{f}_{\mathrm{y}}=500 \mathrm{MPa} \\
v=0,3\end{array}$ & Elastic behavior \\
\hline Soil 1 & Solid 65 & - & $\begin{array}{c}\mathrm{E}_{\text {solo }}=46 \mathrm{MPa} \\
\mathrm{C}=15 \mathrm{KPa} \\
\phi_{\text {solo }}=22 \\
v=0,3\end{array}$ & Plastic behavior - Drucker-Prager \\
\hline Soil 2 & Solid 65 & - & $\begin{array}{c}\mathrm{E}_{\text {solo }}=70 \mathrm{MPa} \\
\mathrm{C}=26 \mathrm{KPa} \\
\phi_{\text {solo }}=28 \\
v=0,3\end{array}$ & Plastic behavior - Drucker-Prager \\
\hline Soil 3 & Solid 65 & - & $\begin{array}{c}E_{\text {solo }}=46 \mathrm{MPa} \\
v=0,3\end{array}$ & Elastic behavior \\
\hline Soil 4 & Solid 65 & - & $\begin{array}{c}E_{\text {solo }}=70 \mathrm{MPa} \\
v=0,3\end{array}$ & Elastic behavior \\
\hline Soil 5 & Solid 65 & - & $\begin{array}{c}\mathrm{E}_{\text {solo }}=1000 \mathrm{MPa} \\
v=0,3\end{array}$ & Elastic behavior \\
\hline
\end{tabular}




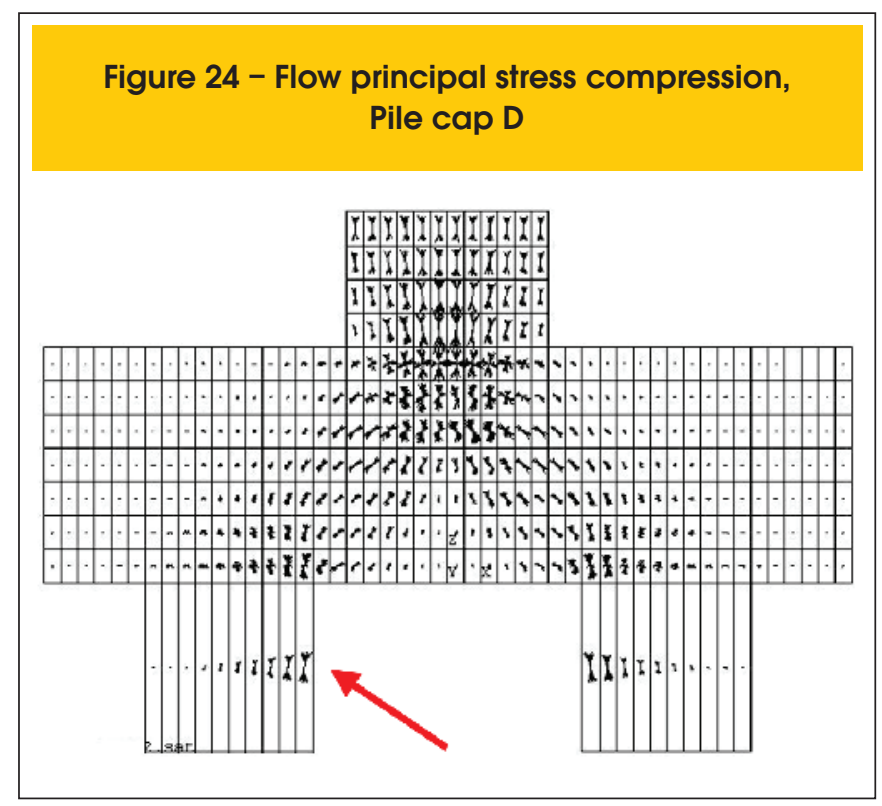

caps boards (sections F and G - Figure [25]) were more solicited than the sections closer to the board (sections $D$ and I - Figure [25]). This phenomenon occurred in all models analyzed.

As a function of the difference between the intensity of forces applied in the pile caps without the presence of the soil (blocks $A$ and $B$ - Figure [20]), which were bigger, in relation to the blocks modeled with the soil (blocks C and D - Figure [20]), occurred differences in the intensities of the main compression stress, what was foreseen, once the rupture of the set soil-structure of the pile caps $C$ and $D$ occurred by the soil.

Through the values presented in Table [4] it is possible to conclude that the sections $F$ and $G$, in the inferior nodal zone (near the piles) were more requested, because with the distribution of the stress deriving from the strut does not happen uniformly on the "head" of the piles, the regions closer to the column were the ones which presented higher stress. These results are similar to the experimental results obtained by Delalibera \& Giongo [25].

According to these results, all analyses developed were performed using short piles, because it was found that the distribution of the flows of main compression stress is little influenced by the piles rigidity.

An interesting result observed during these analyses was in rela-
Figure 25 - Nodal sections investigated

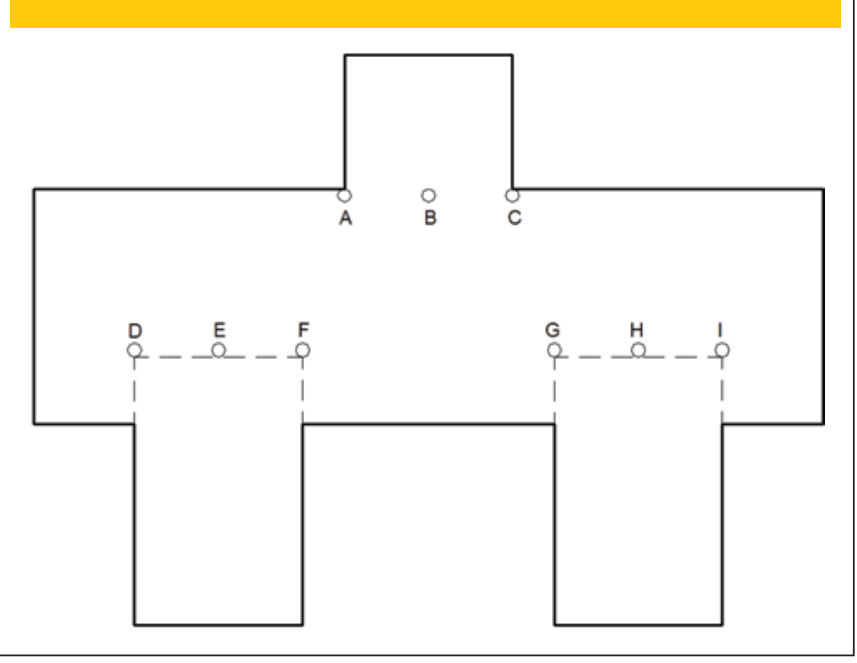

tion to standardization of the main stress of compression on the piles. In blocks B, C and D (see Figure [20]), which had long length piles, it was checked that the stress were uniformed nearly to $1 / 3$ of the height of the pile shaft.

\section{Analysis of variance}

The analysis of variance is a statistics test widespread among the statistical professionals and fundamentally aims at verifying if there is substantial difference among the averages and if the factors exercise influence on any dependent variable.

The proposed values can be of qualitative or quantitative origin, but the dependent variable must be necessarily continuous.

The main application of ANOVA (analysis of variance) is the comparison of averages coming from different groups, also called treatments. There are two kinds of problems to be solved by ANOVA: fixed factors or random factors. The randomness determines the question of the problem.

In most of the cases they are risk factors, after all, the second kind of problem (random) will only emerge when a study involving random choice of factors is performed.

The variance analysis is broadly used in several areas. In Civil

Table 4 - Intensities compressive principal stress, considering the influence of the piles and soil

\begin{tabular}{|c|c|c|c|c|}
\hline \multirow{2}{*}{ Section } & \multicolumn{4}{|c|}{ Tensões principais de compressão (MPa) } \\
\hline & Pile cap A & Pile cap B & Pile cap C & Pile cap D \\
\hline A & 16,7 & 11,5 & 13,3 & 11,7 \\
\hline B & 11,9 & 7,5 & 22 & 21,3 \\
\hline C & 16,7 & 11,5 & 13,3 & 11,7 \\
\hline$D=I$ & 5,10 & 3,5 & 4,2 & 2,10 \\
\hline$E=H$ & 10,9 & 7,5 & 13,3 & 11,7 \\
\hline$F=G$ & 28,3 & 19,5 & 30,6 & 21,3 \\
\hline
\end{tabular}


Table 5 - Analysis of Variance, addressing general, Montgomery (24)

$\begin{array}{ccccc}\text { Factor } & \text { Sum of squares } & \text { Freedom degrees } & \text { Square average } & \mathrm{F}_{0} \\ \mathrm{M} & \mathrm{SS}_{\mathrm{M}} & \mathrm{a}-1 & \mathrm{MSM}=\mathrm{SSM} /(\mathrm{a}-1) & \mathrm{F}_{0}=\frac{\mathrm{MS}_{\mathrm{M}}}{\mathrm{MS}_{\mathrm{E}}} \\ \mathrm{N} & \mathrm{SS}_{\mathrm{N}} & \mathrm{b}-1 & \mathrm{MSN}=\mathrm{SSN} /(\mathrm{b}-1) & \mathrm{F}_{0}=\frac{\mathrm{MS}_{\mathrm{N}}}{\mathrm{MS}_{\mathrm{E}}} \\ \mathrm{M} \times \mathrm{N} & \mathrm{SS}_{\mathrm{MN}} & (\mathrm{a}-1) \cdot(\mathrm{b}-1) & \mathrm{MSMN}=\mathrm{SSMN} /((\mathrm{a}-1) \cdot(\mathrm{b}-1)) & \mathrm{F}_{0}=\frac{\mathrm{MS}_{\mathrm{MN}}}{\mathrm{MS}_{\mathrm{E}}} \\ \text { Error } & \mathrm{SS}_{\mathrm{E}} & \mathrm{abc} \cdot(\mathrm{n}-1) & \mathrm{MSE}=\mathrm{SSE} /(\mathrm{abc} \cdot(\mathrm{n}-1)) & - \\ \text { Total } & \mathrm{SS}_{\mathrm{T}} & \mathrm{abcn}-1 & - & -\end{array}$

Engineering, its use is still restricted, but, there are already works developed using the technique, as: Lima Júnior [20], Delalibera [5] and Pituba et al. [21].

In the variance analysis developed in this work, we used fixed factors, choosing three study variables: the embed length of the column in the sockets $\left(\ell_{\text {emb }}\right)$; the thickness of the pile caps bottom "slab" $\left(h_{s}\right)$; and the wall conformation of the embed chalice and the precast column. The variables chosen totalized eighteen cases of combinations. The models were divided in two groups (smooth walls $-L$ and rough walls $-R$ ).

\subsection{Formulation of the variance analysis}

Being $N$ and $M$ the main fixed factors of the variance analysis, $a, b$ and $c$, the variations of these factors and $n$ the number of replicas. In general there will be $a b c . . . n$ possible combinations. If all the experiment factors are fixed, the problems can be easily formulated, obtaining results that indicate which of the analyzed factors are important as well as their combinations. Table [5] presents a variance analysis with two factors.

To verify the relevance of a determined fixed principal factor or combinations among the main factors, it occurs the relation between the average of the squares of each main factor or combination of the main factors by the average of the squares of the mistakes. The division between the average of the squares of each main factor or combination of main factors by the average of mistakes is called $\mathrm{F}_{0}$.

The number of freedom degrees of each main factor is equal to the number of variations of each factor less the unity. The number of freedom degrees of the main factors combined is the product between the main factors which were combined.

The total sum of the squares is calculated through Equation [1]. The sum of the squares of the combination $\mathrm{N} \times \mathrm{M}$ is expressed through Equation [2]. The sum of the squares of the mistake is defined by Equation [3].

$$
S S_{T}=\sum_{i=1}^{a} \sum_{j=1}^{b} \sum_{k=1}^{c} \sum_{l=1}^{n} y_{i j k l}^{2}-\frac{y^{2} \ldots .}{a b c \ldots n}
$$

$$
S S_{M N}=\sum_{i=1}^{a} \sum_{j=1}^{b} \frac{y_{i j . .}^{2}}{c n}-\frac{y_{\ldots .}^{2}}{a b c . . n}-S S_{M}-S S_{N}
$$

$$
S S_{E}=S S_{T}-\sum_{i=1}^{a} \sum_{j=1}^{b} \sum_{k=1}^{c} \frac{y_{. j j k .}^{2}}{n}-\frac{y^{2} \ldots . .}{a b c . . n}
$$

To verify the relevance of a determined main variable fixed or combined, it is applied test $F$. Through tabulated values of $F_{\text {critical' }}$, provided by Montgomery [24], it is compared the value calculated of $F_{0}$ with the value of $F_{\text {critical }}$. If the calculated value of $F_{0}$ is higher than the tabulated value of $F_{\text {critical }}$ it means that this factor is relevant, otherwise, it implies that the factor does not have substantial importance. The values of $F_{\text {critical }}$ are a function of the number of freedom degrees and of each variable and of the total freedom degrees number.

\section{Results obtained}

\subsection{Analysis of two pile caps - normal force, moment and smooth walls}

Nine pile caps solicited by action of normal force of compression and moment were analyzed (the moment applied to the pile cap was obtained through application of a horizontal force applied on the top of the column). The pile caps presented variations in the embed length of the column ( $\left.\ell_{\text {emb }}\right)$ and in the thickness of the "slab" of pile cap bottom $\left(h_{s}\right)$. The variation of the factors analyzed modified substantially the distribution of the main stress of compression and the panorama of cracks in the last force increment applied to the models. Table [6] presents the results of the numerical analyses performed.

Considering the results of Table [6], it can be observed that for minor embed lengths of the column and minor thicknesses of the bottom slab (in case of the models Lle60hs10NM and Lle50hs10NM) occurred substantial differences in relation to the analytical values. 


\section{Table 6 - Analysis of variance, ANOVA, blocks with smooth conformation and action of compressive force eccentric}

\begin{tabular}{|c|c|c|c|c|c|c|c|c|c|c|c|c|}
\hline \multirow{2}{*}{$\begin{array}{l}\text { Pile } \\
\text { caps }\end{array}$} & \multirow{2}{*}{$\begin{array}{l}\text { Measure } \\
\text { the sides } \\
\text { of the } \\
\text { column } \\
\text { (cm) }\end{array}$} & \multirow{2}{*}{$\begin{array}{c}\text { Measure } \\
\text { the sides } \\
\text { of the } \\
\text { piles } \\
\text { (cm) }\end{array}$} & \multirow{2}{*}{$\begin{array}{c}\mathrm{h}_{\mathrm{s}} \\
(\mathrm{cm})\end{array}$} & \multirow{2}{*}{$\begin{array}{l}\ell_{\text {emb }} \\
(\mathrm{cm})\end{array}$} & \multirow{2}{*}{$\underset{\text { (graus) }}{\Theta}$} & \multirow{2}{*}{$\begin{array}{c}\mathrm{h} \\
(\mathrm{cm})\end{array}$} & \multicolumn{2}{|c|}{$\begin{array}{c}F_{u} \\
(k N)\end{array}$} & \multirow{2}{*}{$F_{\text {blévot }} / F_{\text {num }}$} & \multirow{2}{*}{$\begin{array}{c}e \\
(\mathrm{~cm})\end{array}$} & \multicolumn{2}{|c|}{$\begin{array}{c}A_{b, e s t} \\
\left(\mathrm{~cm}^{2}\right)\end{array}$} \\
\hline & & & & & & & Blévot & Num. & & & Blévot & Num. \\
\hline Ll_80hs30NM & $20 \times 20$ & $20 \times 20$ & 30 & 80 & 54,0 & 120 & 3663 & 3663 & 1,27 & 2,44 & 323,6 & 269,6 \\
\hline Lle80hs20NM & $20 \times 20$ & $25 \times 25$ & 20 & 80 & 51,3 & 110 & 3415 & 3415 & 1,17 & 3,00 & 487,8 & 365,8 \\
\hline L $\ell_{e} 80 \mathrm{hs} 10 \mathrm{NM}$ & $20 \times 20$ & $30 \times 30$ & 10 & 80 & 48,4 & 100 & 3128 & 3128 & 1,28 & 2,84 & 673 & 639,4 \\
\hline Ll $60 \mathrm{hs} 30 \mathrm{NM}$ & $20 \times 30$ & $20 \times 20$ & 30 & 60 & 48,4 & 100 & 3128 & 3128 & 1,18 & 2,90 & 299,1 & 299,1 \\
\hline Ll 60hs20NM & $20 \times 30$ & $25 \times 25$ & 20 & 60 & 45,0 & 100 & 2800 & 2800 & 1,22 & 4,35 & 441,9 & 397,7 \\
\hline Ll 60hs10NM & $20 \times 30$ & $30 \times 30$ & 10 & 60 & 41,2 & 80 & 2428 & 2428 & 1,91 & 5,96 & 592,8 & 497,9 \\
\hline Ll 50hs30NM & $20 \times 40$ & $20 \times 20$ & 30 & 50 & 45,0 & 90 & 2800 & 2800 & 1,24 & 3,59 & 282,8 & 207,3 \\
\hline Ll 50hs20NM & $20 \times 40$ & $25 \times 25$ & 20 & 50 & 41,2 & 80 & 2428 & 2428 & 1,96 & 4,01 & 411,7 & 288,2 \\
\hline Ll,50hs10NM & $20 \times 40$ & $30 \times 30$ & 10 & 50 & 36,9 & 70 & 2016 & 2016 & 3,16 & 4,44 & 355,9 & 177,9 \\
\hline
\end{tabular}

Note: Num., value obtained by numerical simulation Blévot, value calculated using the criteria Blévot \& Fremy (4) $F_{u}$, Rupture force applied in the column, and eccentricity of the normal force, $A_{b, e s t}$, area of the strut near the column.

This shows that the resistant capacity of the block cannot be determined in function of the rupture of the compressed diagonal, but by the puncturing effect of the bottom "slab". It is interesting to observe that, the puncturing effect will only occur if, and only if, the force on the column is transmitted (almost all) to the bottom "slab" and, this will only happen if the embed length is small, not being possible the formation of the connection (or stanchion), being the element rupture characterized by punching shear.

Figure [26] presents bends "reaction in the most solicited pile vs. displacement in the middle of the pile cap span" for the models numerically analyzed.

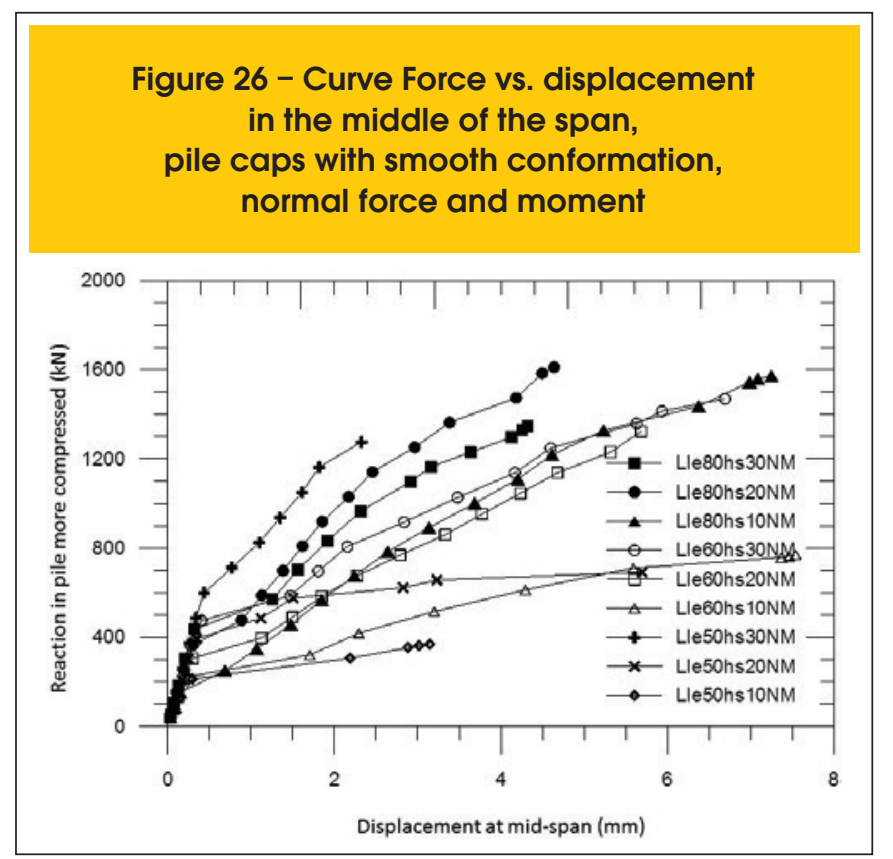

Figure [27] shows the distribution of the main stress of compressions inside one of the numerically analyzed pile caps and Figure [28] shows the panorama of cracking of the same pile cap presented in Figure [27], referring to the last force increment.

For the pile caps models with conformation of the sockets and column walls, with performance of normal force and moment in the pile cap, factor $\ell_{\text {emb }}$ is the main relevant factor, followed by factor $h_{s}$. Table [7] shows the results of the analysis of variance of the pile caps models with conformation of the walls of the sockets and col-

Figura 27 - Principal stress compression, pile cap with smooth conformation, normal force and moment

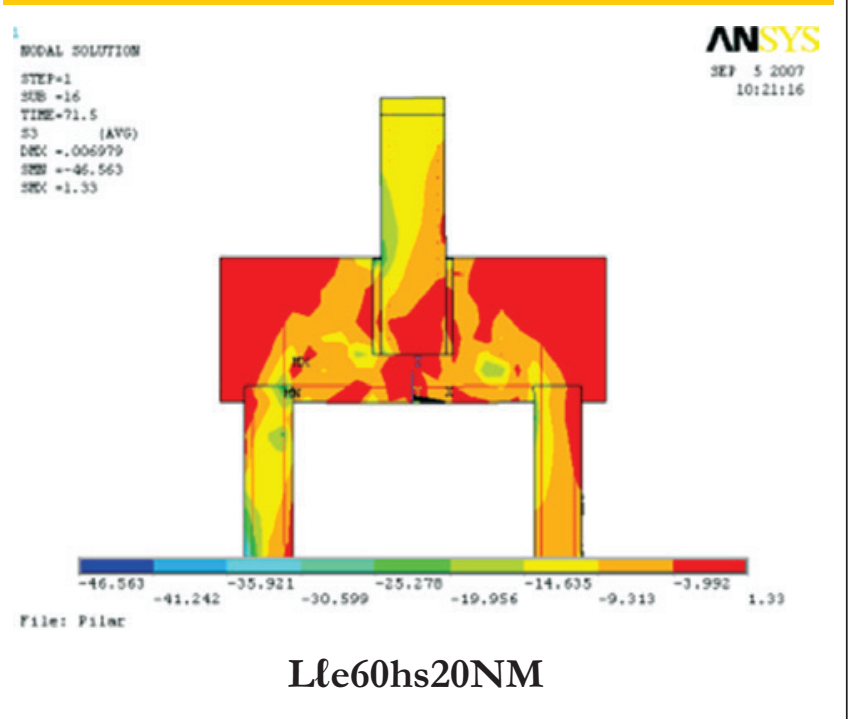




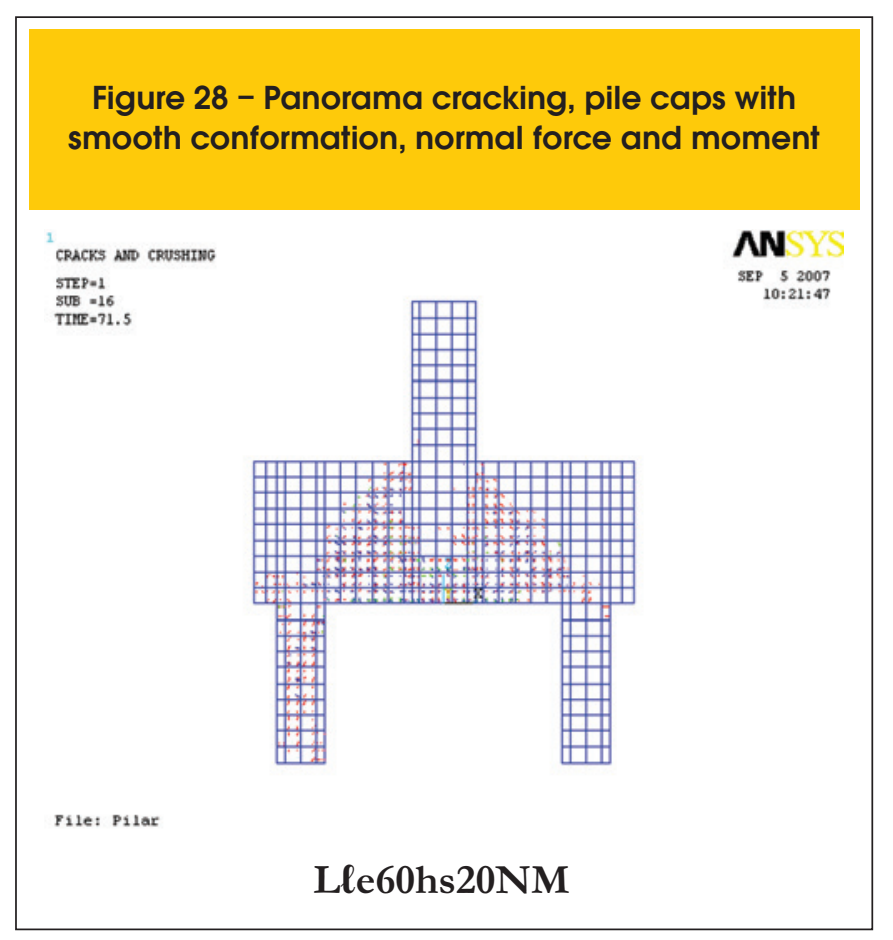

umn, with performance of normal force and moment in the block. Through numerical analysis, it was observed that the existing differences in the areas of the struts with the piles, when compared to the areas of the strut calculated using the criteria by Blévot \& Frémy [4] also occurred, corroborating with the experimental results found by Delalibera \& Giongo [25]. In Table [6] are presented the results of the areas of strut calculated by Blévot criterion (considering a slant of $\theta$ ) and the areas of the strut obtained numerically (for the calculation of the areas of the strut obtained through numerical results, it was used the values of the main compression stress with the piles), as well as the eccentricities of the normal force of each model.

\subsection{Analysis of the two pile caps - normal force, moment and rough walls}

Nine pile caps solicited by action of normal compression force and moment were analyzed, with variations in the embed length of the column $\left(\ell_{\text {emb }}\right)$ and in the thickness of the bottom pile cap
Figura 29 - Principal stress compression, pile cap with rough conformation, normal force and moment

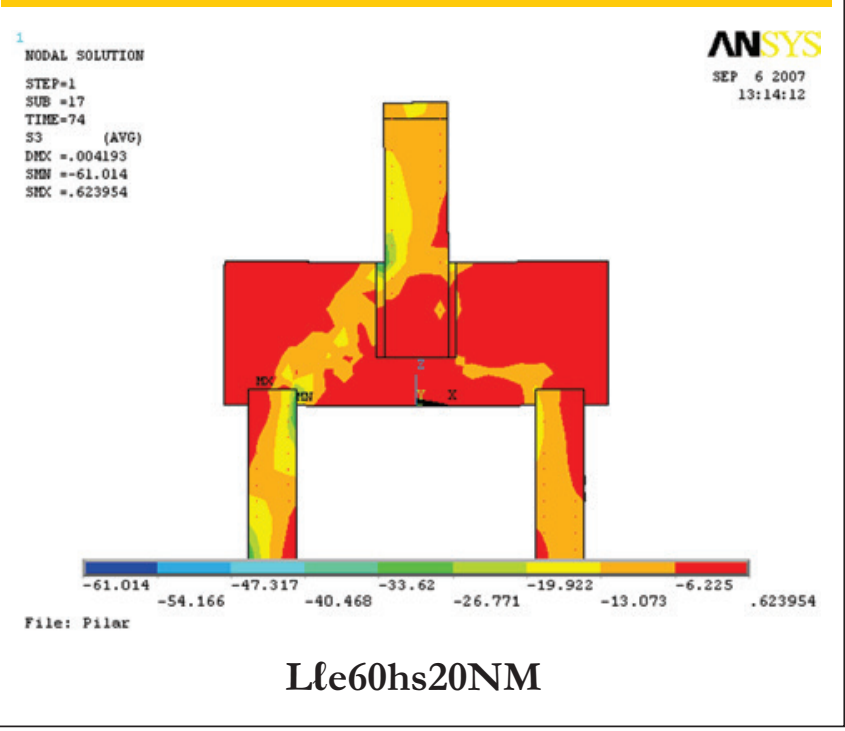

"slab" $\left(h_{s}\right)$. The variation of the factors analyzed modified, also in this case, the distribution of the main compression stress and the crack panorama in the last forces increment (horizontal and vertical) applied to the models. Table [8] presents results of the numerical analyses, Figure [29] shows the distribution of the main compression stress and Figure [30] the crack panorama of the pile caps numerically analyzed.

The cause of the precocious rupture of the model Rle60hs10NM is probably related to the punching shear of the "bottom slab" of the pile cap and the rupture of the model Rle50hs20NM, due to the small embed length of the column.

Through Table [8], it can be observed the differences among the areas of the strut with the piles, calculated by analytic criterion developed by Blévot \& Frémy [4] and using the numerical models. In the same table, are presented the values of the eccentricities of the normal force of each model numerically analyzed.

It is possible to observe through Figures [29] and [30] the formation of the compressed diagonals and the panorama of cracking of one of the blocks numerically analyzed. It is noted that the strut and tie

\section{Table 7 - Analysis of variance, ANOVA, pile caps with smooth conformation and action of compressive force eccentric}

\begin{tabular}{cccccc} 
Factor & Sum of squares & Freedom degrees & Square average & $F_{0}$ & \multicolumn{2}{c}{ Significance $F_{0,01}$} \\
$\ell_{\text {emb }}$ & 2805913 & 2 & 1402956 & 21,67 & 8,65 \\
$\mathrm{~h}_{\mathrm{s}}$ & 2026374 & 2 & 1013187 & 15,65 & 8,65 \\
$\ell_{\text {emb }} \times \mathrm{h}_{\mathrm{s}}$ & 302545 & 4 & 75637,5 & 1,16 & 7,01 \\
Erro & 194219 & 3 & 64734 & - & - \\
Total & 5329056 & 8 & 666132 & - & - \\
\hline
\end{tabular}

Note: $\ell_{\text {emb }} \times h_{s}$, coupling between the embedded length and the thickness of the column "slab" background. 


\section{Table 8 - Results obtained by numerical analysis for blocks with rough conformation} and action of compressive force eccentric

\begin{tabular}{|c|c|c|c|c|c|c|c|c|c|c|c|c|}
\hline \multirow{2}{*}{$\begin{array}{l}\text { Pile } \\
\text { caps }\end{array}$} & \multirow{2}{*}{$\begin{array}{l}\text { Measure } \\
\text { the sides } \\
\text { of the } \\
\text { column } \\
\text { (cm) }\end{array}$} & \multirow{2}{*}{$\begin{array}{c}\text { Measure } \\
\text { the sides } \\
\text { of the } \\
\text { piles } \\
\text { (cm) }\end{array}$} & \multirow{2}{*}{$\begin{array}{c}h_{\mathrm{s}} \\
(\mathrm{cm})\end{array}$} & \multirow{2}{*}{$\begin{array}{l}\ell_{\text {emb }} \\
(\mathrm{cm})\end{array}$} & \multirow{2}{*}{$\underset{\text { (graus) }}{\theta}$} & \multirow{2}{*}{$\begin{array}{c}\mathrm{h} \\
(\mathrm{cm})\end{array}$} & \multicolumn{2}{|c|}{$\begin{array}{c}F_{u} \\
(k N)\end{array}$} & \multirow{2}{*}{$F_{\text {blévot }} / F_{\text {num }}$} & \multirow{2}{*}{$\begin{array}{c}e \\
(\mathrm{~cm})\end{array}$} & \multicolumn{2}{|c|}{$\begin{array}{l}A_{b, e s t} \\
\left(\mathrm{~cm}^{2}\right)\end{array}$} \\
\hline & & & & & & & Blévot & Num. & & & Blévot & Num. \\
\hline $\mathrm{Rl}_{\mathrm{e}} 80 \mathrm{hs} 30 \mathrm{NM}$ & $20 \times 20$ & $20 \times 20$ & 30 & 80 & 54,0 & 120 & 3663 & 2832 & 1,29 & 3,18 & 323,6 & 223,8 \\
\hline $\mathrm{Rl}_{\mathrm{e}} 80 \mathrm{hs} 20 \mathrm{NM}$ & $20 \times 20$ & $25 \times 25$ & 20 & 80 & 51,3 & 110 & 3415 & 2660 & 1,28 & 3,76 & 487,8 & 404,9 \\
\hline $\mathrm{Rl}_{\mathrm{e}} 80 \mathrm{hs} 10 \mathrm{NM}$ & $20 \times 20$ & $30 \times 30$ & 10 & 80 & 48,4 & 100 & 3128 & 2460 & 1,27 & 3,48 & 673 & 639,4 \\
\hline $\mathrm{Rl}_{\mathrm{e}} 60 \mathrm{hs} 30 \mathrm{NM}$ & $20 \times 30$ & $20 \times 20$ & 30 & 60 & 48,4 & 100 & 3128 & 2360 & 1,33 & 3,93 & 299,1 & 299,1 \\
\hline $\mathrm{Rl} \ell_{\mathrm{e}} 60 \mathrm{hs} 20 \mathrm{NM}$ & $20 \times 30$ & $25 \times 25$ & 20 & 60 & 45,0 & 100 & 2800 & 2368 & 1,18 & 4,74 & 441,9 & 371,2 \\
\hline $\mathrm{Rl}_{\mathrm{e}} 60 \mathrm{hs} 10 \mathrm{NM}$ & $20 \times 30$ & $30 \times 30$ & 10 & 60 & 41,2 & 80 & 2428 & 1103 & 2,20 & 7,13 & 592,8 & 462,4 \\
\hline $\mathrm{Rl} \ell_{\mathrm{e}} 50 \mathrm{hs} 30 \mathrm{NM}$ & $20 \times 40$ & $20 \times 20$ & 30 & 50 & 45,0 & 90 & 2800 & 2260 & 1,24 & 3,91 & 282,8 & 243,2 \\
\hline $\mathrm{R} \ell_{\mathrm{e}} 50 \mathrm{hs} 20 \mathrm{NM}$ & $20 \times 40$ & $25 \times 25$ & 20 & 50 & 41,2 & 80 & 2428 & 1253 & 1,94 & 5,03 & 411,7 & 308,8 \\
\hline $\mathrm{R} \ell_{\mathrm{e}} 50 \mathrm{hs} 10 \mathrm{NM}$ & $20 \times 40$ & $30 \times 30$ & 10 & 50 & 36,9 & 70 & 2016 & 1828 & 1,10 & 4,47 & 355,9 & 153,1 \\
\hline
\end{tabular}

Note: Num., value obtained by numerical simulation Blévot, value calculated using the criteria Blévot \& Fremy (4) $F_{u}$, Rupture force applied in the column, and eccentricity of the normal force, $A_{b, e s t}$, area of the strut near the column.

model must be modified according to the external actions acting on the pile cap, i.e., idealize a model that contemplates the actions of moment, normal force and horizontal force.

Figure [31] shows bends "reaction in the most solicited pile vs. displacement in the middle of the pile cap span".

The behavior of the pile cap submitted to the action of moment and compression force, indicate that the pile caps with more rigidity present higher bearing capacity and the presence of moment in them, reduce it. Delalibera [5] experimentally proves this statement.

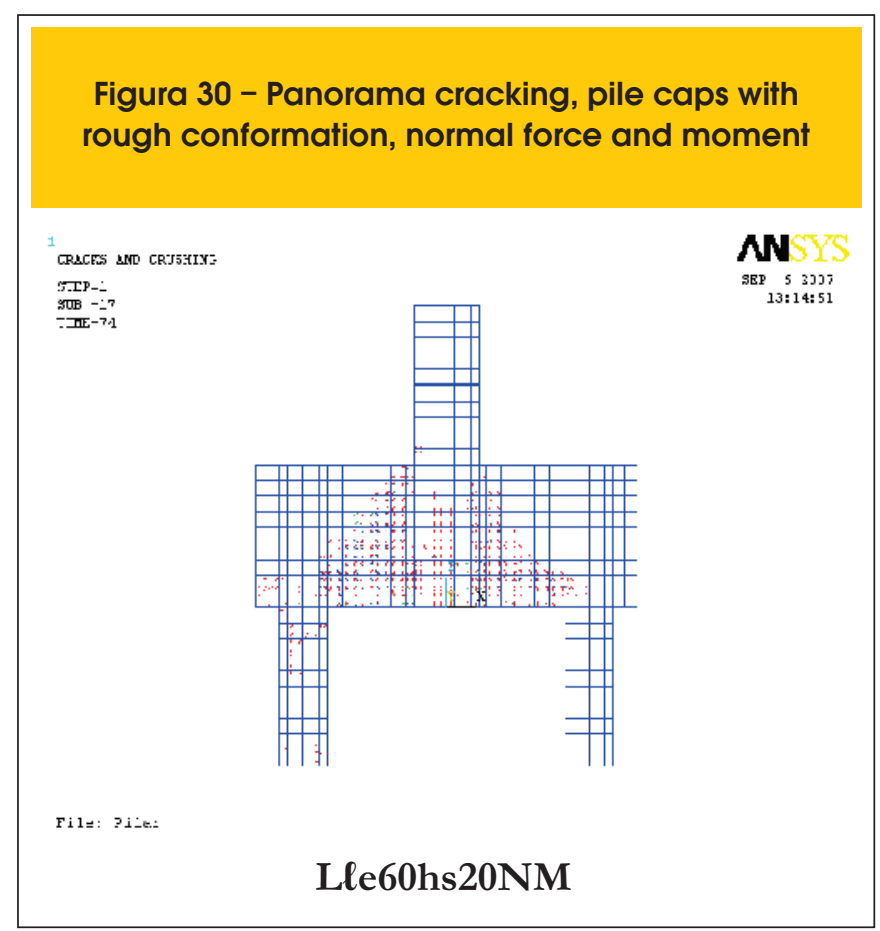

Delalibera \& Giongo [26], analyzed the same pile caps of this work, but it was applied only centered compression force. It was observed that the bearing capacity of the pile caps with only centered force was superior to the pile caps with eccentric force.

Table [9] presents the results of the variance analysis of the pile caps submitted to eccentric compression force and rough conformation of the column-sockets interface.

Another very interesting result consistent with statements of other researchers can be observed through the values of Table [9]. As the link with the shear key grants the link column-foundation monolithic behavior, it is expected that the rupture of the pile caps is associated to other factors. It was verified, because, it is noted that

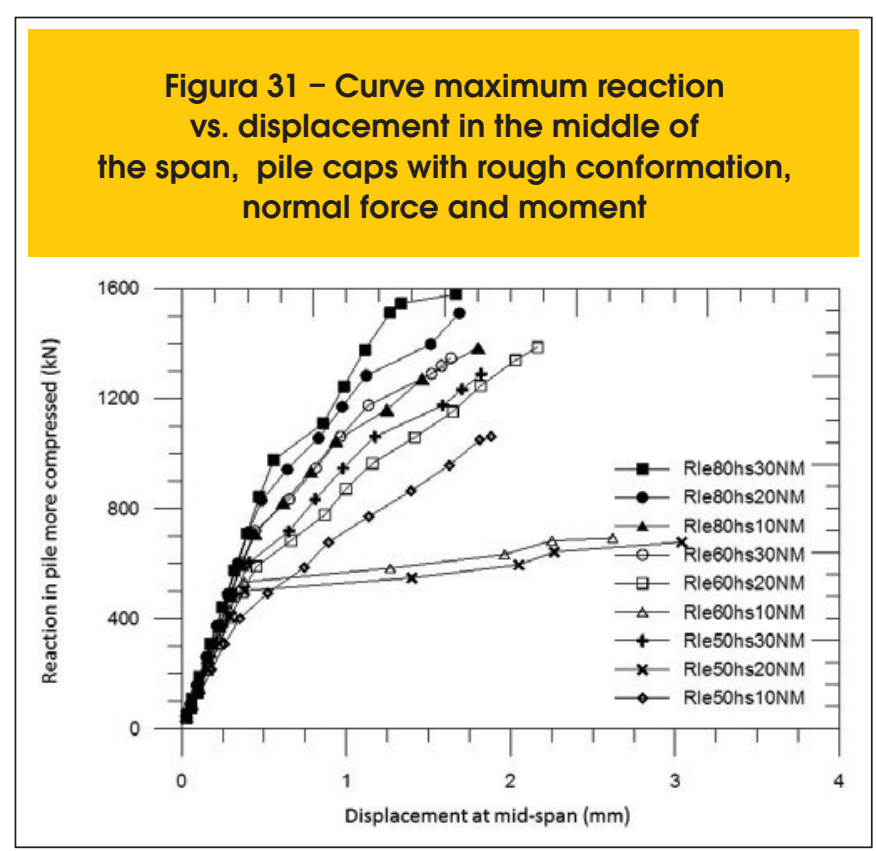




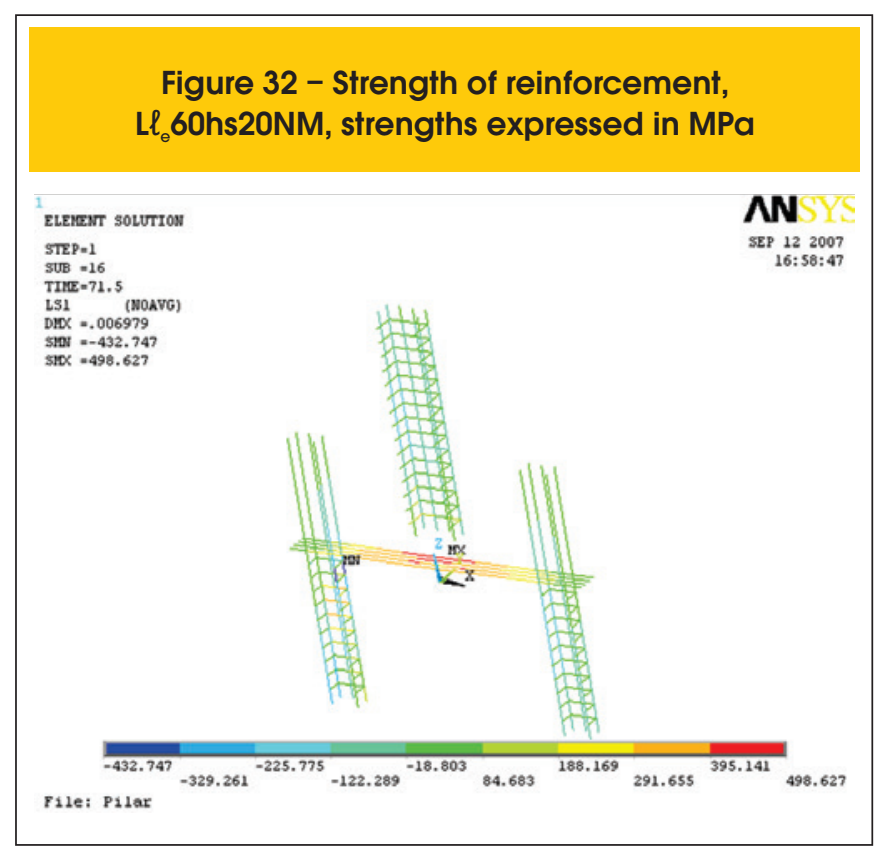

the factors previously chosen for this analysis were not relevant, i.e., did not present substantial values. Such results corroborate with the results presented by Canha \& El Debs [14], where it was found that respecting the minimal embed length of the column established by NBR 9062:2006, it can be considered monolithic the behavior of the link column-sockets.

\subsection{Stress on the steel bars}

Analyzing Figure [32], it can be noticed that reinforcement of the models presented consistent values and in some cases, occurred yield. It was observed that in some reinforcement of the piles, occurred traction tensions. These results are coherent as a function of the external actions applied.

The results presented in Figure [32] corroborate with the results presented by Adebar et al. [7], Miguel [6] and Delalibera [5], i.e., the stress in the reinforcement is not constant, having null values (or even negative) on the tip of the rods and maximum values in the middle of the span. It can also be observed that, the reinforcement that of the piles present stress with different values, what indicates flexion-compression on the piles.

\section{Conclusion}

The numerical simulations proved to be coherent and pointed tendency of the structural behavior of two pile caps with embed socket, with smooth and rough conformation of the socket walls and of the columns.

It was observed for the pile caps with smooth interface between the socket and column walls, the following factors: embed length of the column $-\ell_{\text {emb }}$ and thickness of the bottom slab $h_{s}$, has got relevant importance in the bearing capacity of the models. Because, the models numerically analyzed with bigger embed lengths of the column and bigger thicknesses of the bottom "slab", presented higher bearing capacity. Furthermore, it was evident that in the situations in which there was embed length of the column diminished and small thickness of the bottom "slab", the possible ruin occurred by punching shear of the pile caps in the region of contact between the column base and the pile cap base.

For the models simulated with rough interface between the socket and column (shear key), the factors analyzed $\left(\ell_{\text {emb }}\right.$ and $\mathrm{h}_{\mathrm{s}}$ ) were not relevant in the determination of the bearing capacity of the pile caps. These results are interesting, because it is possible to project pile caps with embed socket and shear key, with strut and tie model, only getting worried with the punching shear of the bottom "slab" of the pile cap, during the assembling phase (i.e., before the application of the filling material), since respecting the minimal embed length of the column in the socket, suggested by NBR 9062:2006. It is necessary a higher number of experimental tests, so that it can be verified the possibility of the reduction of the embed length of the column in the socket.

It was also observed that the rigidity of the pile cap influences in the bearing capacity of it. This can be stated as a function of the results obtained, because the models with higher heights were the ones that presented higher resistant capacity.

It was found, and it was expected, that the models numerically analyzed with smooth interface, presented minor bearing capacity in relation to the models numerically analyzed with rough interface.

\section{Acknowledgments}

To: CNPq - Conselho Nacional de Desenvolvimento Científico e Tecnológico and to FAPESP - Fundação de Amparo à Pesquisa do Estado de São Paulo for the financial support to perform the research that made it possible to write this paper.

Table 9 - Analysis of variance, ANOVA, blocks with rough conformation and action of compressive force eccentric

\begin{tabular}{cccccc} 
Factor & Sum of squares & Freedom degrees & Square average & $F_{0}$ & Significance $F_{0,01}$ \\
$\ell_{\text {emb }}$ & 1697377 & 2 & 848688 & 1,58 & 8,65 \\
$\mathrm{~h}_{\mathrm{s}}$ & 875380 & 2 & 437915 & 0,82 & 8,65 \\
$\ell_{\text {emb }} \times \mathrm{h}_{\mathrm{s}}$ & 43964 & 4 & 10991 & 0,02 & 7,01 \\
Erro & 1606137 & 3 & 535379 & - & - \\
Total & 4223308 & 8 & 527913 & - & - \\
\hline
\end{tabular}

Note: $\ell_{\text {emb }} \times h_{s}$, coupling between the embedded length and the thickness of the column "slab" background. 


\section{Bibliographical references}

[01] ASSOCIAÇÃO BRASILEIRA DE NORMA TÉCNICAS, ABNT NBR 6118:2003 Projeto de estruturas de concreto, 2007. Rio de Janeiro.

[02] ASSOCIAÇÃO BRASILEIRA DE NORMA TÉCNICAS, ABNT NBR 9062:2005 Projeto e execução de estruturas de concreto pré-moldado, 2006. Rio de Janeiro.

[03] EN 1992-1-1, Eurocode 2: Design of concrete structures - Part 1-1: General rules and rules for buildings, 2004. European standard.

[04] BLÉVOT, J.; FRÉMY, R.. Semelles sur piex. Analles d'Institut Techique du Bâtiment et des Travaux Publics, Paris,1967, v. 20, n. 230, p. 223-295, fev.

[05] DELALIBERA, R. G.. Análise teórica e experimental de blocos de concreto armado sobre duas estacas submetidos a ação de força centrada e excêntrica. Tese (doutorado) - Escola de Engenharia de São Carlos, Universidade de São Paulo, 2006, São Carlos.

[06] MIGUEL, G. M.. Análise experimental e numérica de blocos sobre três estacas. Tese (doutorado) - Escola de Engenharia de São Carlos, Universidade de São Paulo, 2000, São Carlos.

[07] ADEBAR, P.; KUCHMA, D.; COLLINS, M. P.. Strut-and-tie models for design of pile caps: an experimental study. ACI Journal, 1990, v. 87, p. 81-91, Jan/Feb.

[08] MONTOYA, P.J.; MESEGUER, A.; CABRE, M. Hormigon Armado 14.a Edición Basada em EHE ajustada al Código Modelo y al Eurocódig, 2000. Barcelona, Gustavo Gili.

[09] KACHLAKEV, D.; MILLER, T; YIM, S.; CHANSAWAT, K.; POTISUK, T.. Finite element modeling of reinforced concrete structures strengthened with frp laminates. Final Report, 2001. Oregon Department of Transportation, May.

[10] NIESEN, M. P.. Limit analysis and concrete plasticity. Prentice-Hall series in Civil Engineering, Englewood Cliffs, 1984. New Jersey, 420 pg.

[11] CANHA, R. M. F.. Estudo teórico-experimental da ligação pilar-fundação por meio de cálice em estruturas de concreto pré-moldado. Tese (Doutorado), Escola de Engenharia de São Carlos, Universidade de São Paulo, 2004. São Carlos.

[12] EBELING, E. B.. Análise da base de pilares pré-moldados na ligação com cálice de fundação. Dissertação (Mestrado), Escola de Engenharia de São Carlos, Universidade de São Paulo, 2006. São Carlos.

[13] OSANAI, Y.; WATANABE, F.; OKAMOTO, S.. Stress transfer mechanism of socket base connections with precast concrete columns. ACI Structural journal, 1996, v. 93, n. 3, p. 226-276, May/June

[14] CANHA, R. M. F.; EL DEBS, M. K.. Proposta de modelo de prometo para a ligação pilar-fundação por meio de cálice em estruturas de concreto pré-moldado. Revista Ibracon de Estruturas, 2006. Vol. 2, $\mathrm{n}^{\circ}$. 2, p. 137-166, junho.
[15] MAUTONI, M.. Blocos sobre dois apoios. Grêmio Politécnico, 1972. São Paulo.

[16] ABEBAR, P.. One-way shear strength of large footings. Can. J. Civ. Eng, 2000. 27: 553-562.

[17] SAM, C., IYER, P. K.. Nonlinear finite element analysis of reinforced concrete four-pile caps. International Journal of Structures, 1995, v. 15, n. 1, p. 18-34, Jan/Jun.

[18] SENNA JÚNIOR, R. S.. Distribuição de carga em grupos de estacas escavadas de pequeno diâmetro. Dissertação (Mestrado), Escola de Engenharia de São Carlos, Universidade de São Paulo, 1993. São Carlos.

[19] VELLOSO, D. A.; LOPES, F. R.. Fundações. COPPE/ UFRJ, 1996. Rio de Janeiro.

[20] LIMA JÚNIOR, H. C.. Avaliação da ductilidade de pilares de concreto armado, submetidos a flexo-compressão reta com e sem adição de fibras metálicas. Tese (Doutorado), Escola de Engenharia de São Carlos, Universidade de São Paulo, 200., São Carlos.

[21] PITUBA, J. J. C. ; DELALIBERA, R. G.; RODRIGUES, F. S. . Numerical and Statistical Analysis about Displacements in Reinforced Concrete Beams using Damage Mechanics, 2012. Computers and Concrete, an International Journal (Print).

[22] DELALIBERA, R. G.. Análise numérica de blocos sobre duas estacas, com cálice embutido, submetido à ação de força normal e excêntrica. Relatório científico, 2012. Universidade Federal de Goiás / CNPq - Conselho Nacional de desenvolvimento científico e tecnológico.

[23] ANSYS User's Manual. Theory Manual, 2011. ANSYS revision 5.5 .

[24] MONTGOMERY, D. C.. Design and Analysis of Experiments - Fourth Edition, 1996. Arizona State University, John Wiley \& Sons.

[25] DELALIBERA , R. G.; GIONGO, J. S.. Deformations in the strut of two pile caps. Ibracon Structures and Materials Journal - RIEM, 2008, v. 1, p. 121-138.

[26] DELA LIBERA, R. G. ; GIONGO, José Samuel. Análise de variância de blocos sobre duas estacas com cálice embutido,submetido à ação de força de compressão centrada. Revista Eletrônica de Engenharia Civil, 2012, v. 1, p. 1-16. 